\title{
Belge Yönetiminin Değişen Yüzü: Standartlaşma Çalışmaları ve Uluslararası Uygulamalar
}

\author{
Change in the Task of Records Management: \\ Standardization Studies and International Practices
}

\section{Özgür KÜLCÜ*}

\begin{abstract}
Öz
Geleneksel belge yönetimi kurumsal çerçevede belgelerin yönetimine dönük uygulama programlarından oluşmaktadır. Özellikle 90'ı yıllarla birlikte belge yönetimi, değişen koşulların da etkisiyle çok daha geniş çerçevede tanımlanmaya başlanmıştır. Toplumsal yaşamda, yönetim anlayışındaki değişim ve küreselleşme, belge işlemlerinin elektronik ortama taşınması ve elektronik belge yönetimi ile iletişim teknolojileri, belge yönetimi çalışmalarını uluslararası boyuta taşımışır. Bu çerçevede makalede, belge yönetimi alanında geliştirilen ulusal ve uluslararası düzenlemelerin, standartların ve uygulama modellerinin değerlendirilmesi amaçlanmıştır.
\end{abstract}

Anahtar sözcükler: Belge yönetimi, Standartlar, Yenileşim, Elektronik imza, Bilgi Edinme Hakkı Kanunu.

\section{Abstract}

Traditionally records management applications consisted of the practice oriented programs comprising usually the records management in (mostly governmental) institutions. However, especially after $90 \mathrm{~s}$, records management concept has been comprehended and described broader than ever, because of the effects of changing conditions. Developments and globalization in

"Yrd. Doç. Dr.; Hacettepe Üniversitesi Edebiyat Fakültesi Bilgi ve Belge Yönetimi Bölümü (kulcu@hacettepe.edu.tr) 
social life and management approaches, fulfillment of the records processes in electronic media, and through electronic records management and communication technology, records management studies became more and more a concern of the international platform. In that scope, this study aims at evaluating the international and national regulations, standards and practical models in the area of records management.

Keywords: Records management, Standards, Innovations, Electronic signatures, Act on Right of Information Acquisition.

\section{Giriş}

Kurumsal amaçlara yönelik üretilen ve kullanılan belgelerin, tasarımından ayıklanmasına kadar her aşamada etkin yönetimini sağlama, belge yönetiminin çalışma kapsamını ortaya koymaktadır. Belge yönetimi kurumsal iletişimin etkinleşmesi, yönetimin doğru kararlar verebilmesi, geriye dönük uygulamaların ortaya konulabilmesi ve kurumsal denetim sağlanabilmesi için belgelerin doğru zamanda, istenildiği kadar üretilmesi, düzenlenmesi, dağıtılması, saklanması, ayıklanması ve güncelliğini kaybetmesiyle birlikte arşivlere göndermesi ya da kullanım değerini tamamen yitirmesiyle birlikte imhasını amaçlamaktadır. Bu amaçlar kurumsal yönetimin görev ve sorumlulukları arasında sayılmaktadır. Kurumlar yürüttükleri iş ve işlemlere yönelik bilgi ve belge kaynaklarını, yasal düzenlemeler ve idari gereklilikler doğrultusunda yönetmek durumundadırlar. Öte yandan değişen koşullar, bilgi ve belge sistemlerini etkileyebilmekte, yeni koşullara uygun program ve uygulamaların gerçekleştirilmesini gerekli kılabilmektedir.

Çalışmada, bu çerçevede özellikle 70'li yıllarla birlikte belge yönetimi alanında gözlenen değişim, elektronik belgeler ve elektronik belge yönetimi, uluslararası çalışmalara yöneliş ve bu kapsamda geliştirilen belli başlı düzenlemeler, standartlar ve uygulama örnekleri incelenmektedir. Belge yönetimi alanında değişime yön veren iki temel etken olan küreselleşme ve elektronik belge yönetiminin, alanın gelişimine ivme kazandırdığı düşünülmektedir. Bu varsayımı destekleyen gelişmelerin ele alındığı çalışmada, yaşanan sürecin ülkemize yansımalarına da değinilmektedir. Günümüzde standartlaşma kurumsal çevrenin ötesinde uluslararası ilişkilerin vazgeçilmez unsuru haline gelmiştir. 
Kurulan ticari, kültürel, bilimsel vb. çeşitli ilişkiler gün geçtikçe artmakta, elektronik ortamın da etkisiyle mesafe kavramı ortadan kalkmaktadır. Bu çerçevede uluslararası dernek, birlik, oluşum vb. teşkilatlar ortak bir anlayışı ve asgari kalite ölçütlerini belirlemeye ve gerektiğinde denetlemeye yönelmektedirler. Bu gelişmelere belge yönetimi alanı iyi bir örnek oluşturmaktadır. Çalışma içerisinde yer aldığı gibi elektronik ticaret ilkelerini belirlemeye yönelen Birleşmiş Milletler, aynı zamanda elektronik belgelerin geçerliliği ve elektronik imza konusunda çalışmalar yapmak durumunda kalmış, ülkemizin de dâhil olduğu pek çok ülke belirlenen ölçütlere uygun düzenlemeleri yasallaştırmıştır. Yine Uluslararası Standartlar Örgütü ISO (International Standardization for Organization) kurumsal uygulamalara yönelik genel kalite standartlarını, "kalite sistem dokümantasyonu" adı verilen, belge yönetimi ve dokümantasyon çalışmalarına dayanan bir dizi uygulama ölçütü geliştirmiştir.

Çalışma içerisinde değinilen bu ve benzeri uygulamaların geliştirilmesi, kısa sayılabilecek bir sürede ülkemizin de içinde olduğu geniş bir coğrafyada benimsenmesini tetikleyen temel iki etken, küreselleşme ve elektronik uygulamaların yaygınlaşmasıdır.

Çalışmada bu çerçevede, özellikle 90'ı yıllarla birlikte ivme kazanan belge yönetimi alanında gelişmeleri tetikleyen unsurlara yönelik bir durum saptaması yapmak ve geliştirilen düzenleme ve standartlar ile uygulama modellerini değerlendirmek amaçlanmıştır. Bu gelişmelerin yansımalarının küresel etkileri, ilgili alanlarda benzer düzenlemelerin ülkemizin de dâhil olduğu pek çok ülkede yasallaşması ya da yasallaşma aşamasında olmasıyla gözlemlenebilir. Bu kapsamda Avrupa Birliği içerisinde geliştirilen düzenlemeler başka bir çalışmanın konusu olduğundan burada değinilmemiştir.

\section{0’lerden Günümüze Belge Yönetimi Alanında Değişimler}

Günümüzde profesyonel bir disiplin olarak belge yönetiminin çalışma kapsamını, 70'li yıllarla birlikte aldığını söylemek yanlış olmaz. Gerek meslek derneklerinin gerekse belge yönetimi alanında eğitim veren kurumların çabaları, belge yönetimini bağımsız ve profesyonel çalışmaların yürütüldüğü, kendisine ait ilke ve yöntemlere sahip bir disiplin olarak tanımlanmasına olanak 
sağlamıştır. $\mathrm{Bu}$ saptamayı dönemin eğitim programları doğrulamaktadır. 70'lerde ABD'de belge yönetimi eğitimi veren kurumlarda, belge yöneticisi sertifikası (certified records managers) almak için gerekli temel dersler şunlardı:

1. Yönetim prensipleri ve denetim

2. Belge üretimi ve denetim

3. Güncel belge erişim sistemleri

4. Belge ayıklama ve koruma

5. Belge yönetim teknolojisi: mikrografi, veri ve kelime işlemciler

6. Vaka incelemesi (Evans, 1998, s.32)

Görüldüğü gibi bu dönemde belge yöneticisi olma yeterliliği için, öncelikle temel yönetim prensiplerini öğrenmek, daha sonra üretimden son ayıklamaya kadar kurumsal belge işlemlerinin tümüne yönelik uygulamaları kavramak gerekmektedir. Kuramsal eğitimin ardından, gerçekleştirecekleri uygulamalı çalışmalarla belge yöneticisi sertifikası almaya hak kazanılmıştır (Evans, 1998, s.32). Pazarın gerektirdiği iş gücünü yetiştiren eğitim kurumları zamanla değişen gereksinimlerden etkilenmiş, yeni koşullara uyum sağlamış ve dönem dönemde yönlendirebilmişlerdir. Belge yönetim alanın alanı düşünüldüğünde, çalışmaları yönlendirme etkisi ile yönetim sistemleri belirleyici olabilmiştir.

Yönetim yaklaşımlarındaki değişim, yönetim sistemlerinin bir parçası olarak belge çalışmalarını da etkilemiş ve etkilemeye devam etmektedir. Ancak belge yönetimi alanına yön veren temel bir diğer etken de teknolojik gelişmeler olmuştur.

70'lerde fotokopi makineleri ve çoğaltma olanaklarının artışı, 1980'li yılların başıyla birlikte kişisel bilgisayarların kullanılmaya başlanması, 1990'larda İnternet ve Web olanakları, son yıllarda eticaret, yerel ve geniş alan ağları gibi olanakların yaygınlaşması, kurumsal yaşamın bir parçası olarak bilgi profesyonelleri ve belge yöneticilerinin çalışma koşullarını da etkilemiştir. Değişimin yansımaları giderek daha kısa süreler almaktadır. Örneğin telefonun icadından pazara çıkışına kadar 50 yıl geçmesine karşın İnternet'in ortaya çıkışından yalnızca yedi yıl sonra yaygın olarak kullanılmaya başlandığından söz edilmektedir (Eiring, 2002, s.21). Öte yandan değişimin sadece olumlu etkilerinin olduğunu savunmak güçtür. Eiring (2002, s.21)'in verdiği bilgiye göre, 
gelişmiş ülkelerde çalışan nüfusun \%50'si kendi alanlarında sağladıkları bilgiyi kullanamadıkları, \%38'i zamanlarının önemli bir bölümünü gereksiz yere intiyaçları olan bilgiye erişmek için harcadıklarını, \%48'i İnternet'i iş yükünü ve stresini artıran bir araç olarak gördüklerini belirtmişlerdir. Bu örnekler, artan bilgi yığınları ve karmaşıklaşan ilişkiler karşısında, gerekli ve doğru bilgiyi sağlayacak olanaklara duyulan gereksinimin yoğunluğunu ve buna bağlı olarak iş stresinin artışını göstermesi bakımından önemli görülmektedir.

Belge ve arşiv alanında teknolojik etkenlerin 80'li yıllarda hızlandığı, 90’lı yıllara çalışmaların önemli bir bölümünün elektronik ortama taşınmaya başladığı, 2000'li yıllarda küresel ticaretin sanal ortama kaydığı, gelecek on yılda ise bu gelişmelerin, belge yönetimi uygulamalarını bütünüyle kâğıtsız ortama taşıyacağı dile getirilmektedir. Ancak bu gelişmeler bazı sorunları da beraberinde getirmektedir. Örneğin, özellikle 90'lı yıllarla birlikte belge ve doküman yönetimi endüstrisindeki gelişmelerin, alanda yazılım ve donanım üreten birkaç firmayı ön plana çıkardığı ve diğerlerinin pazara girişlerinin oldukça zorlaştığı üzerinde durulmaktadır (Spratt, 2004, s.1). Bu durum belge ve arşiv çalışmalarında standartlaşmanın gelişimi açısından olumlu görülmesine karşın, tekdüzelik ve tekelleşme sorunu dikkat çekicidir.

Kurumsal iletişimin resmi yönünü oluşturan, karar verme sürecini etkileyen verileri sağlayan, uygulamaların beklentileri ne ölçüde karşıladığını tanımlayan belgeler, tüm bu unsurlara yönelik yaklaşımlardaki değişimlerden de doğal olarak etkilenmektedir. Günümüzde belge işlemlerini etkileyen unsurları genel olarak Tablo 1'de yer alan maddelerde toplamak mümkündür.

Tüm bu etkenler ortak çalışmalara duyulan gereksinimi artırmaktadır. 21. yüzyıl bilgi profesyonelliği, belge öneticisi, arşivistler, kütüphaneciler, süreç tasarımcıları, bilgi yöneticileri, bilgi teknolojisi uzmanları, sistem analistleri, iletişim ve ağ profesyonellerinin birlikte çalışmasını gerektirmektedir. Belge yönetimi alanında geliştirilen uygulamaların, düzenlemelerin ve programların pek çok bileşenle birlikte tanımlanması, bu gelişimi doğrulamaktadır. Günümüzde belge yönetim programlarının 
geliştirilmesinde bilgi yöneticileri, belge yöneticileri ve bilgisayar mühendisleri ortak projeler geliştirmek durumundadırlar (Eiring, 2002, s.21; Evans, 1998, s.32).

- Demokrasi kültürünün yaygınlaşması ve serbest girişimcilik: Belgeler toplumsal bir varlık olan insanların ve çeşitli amaçlarla oluşturulmuş kurumsal yapıların mevcut durumunu ve karşıııkı ilişkisini yansıtan ve doğrulayan bir iletişim aracıdır. Günümüzde kurumsal ilişkilerdeki değişim ve yeniden yapılanma, daha açık toplumsal örgütlenmeler, serbest girişimcilik gibi vb doğal olarak ilgili çalışmaların uzantısı olarak belge yönetimini etkilemektedir.

- Küreselleşmenin hız kazanması: Belge yönetiminin özellikle son 15 yılına damgasını vuran en önemli gelişmelerden birisi küreselleşmedir. Küresel girişimlerin bu tarihlerden sonra yoğunlaşması, "uluslararası belge yönetimi" kavramının ortaya çıkışında temel bir etken olarak gösterilmektedir. Her ne kadar 70 'li ve 80 'li yıllarda Uluslararası Belge Yönetimi Konseyi (International Records Management Council) türü oluşumlar gözlense de, ortak çalışmalara yönelik girişimler son yıllarda yoğunlaşmaktadır. Bu noktada uluslararası örgütlerin önemli etkileri olmuştur. Örneğin Avrupa Birliği, Kuzey Amerika'da NAFTA ve GATT gibi serbest ticarete dayalı örgütler küreselleşmeye hız kazandırmıştır. Aynı dönemde Doğu Avrupa, Asya ve Latin Amerika gibi daha önce küreselleşmeye sıcak bakmayan pek çok ülke ya da bölgede de küreselleşme eğilimlerinin hız kazandığından söz edilmektedir (Spratt, 2004, s.4; Stephens, 2001 , s.66). Kurumsal yapıların ve paralel olarak iş koşullarının giderek küreselleşmesi, belge yönetimi alanında ortak yaklaşımların ve projelerin geliştirilmesini de gerekli kılmaktadır. Bu çerçevede değerlendirildiğinde küreselleşme ile birlikte "uluslararası belge yönetimi" kavramının da gelecekte daha yaygın kullanılacağından söz edilebilir.

- Belge yönetim alanında rehberler ve standartların geliştirilmesi: Belge yönetim programlarının uygulanmasına yönelik, genel geçerliliğe sahip rehberler ve standartların sayısı gün geçtikçe artmaktadır. Öte yandan yönetim modelleri ve kalite sistemlerine dönük standartlardan ISO 9000 ve benzeri düzenlemeler içerisinde, kurumsal uygulamalara yönelik bir gereklilik olarak belge yönetiminin tanımlanması, alanın uluslararası gelişimi açısından önemli görülmektedir (Stephens, 2001, s.67). Çalışmanın ilerleyen bölümlerinde geliştirilen standartlar daha geniş olarak incelenecektir.

- Uluslararası düzenlemeler: Kurumlarda hizmetlerin sağlanmasına yönelik iş süreçleri, önceden belirlenmiş düzenlemeler doğrultusunda gerçekleştirilmekte ve her iş beraberinde genellikle bir ya da birden çok belgenin üretimi ile sonuçlanmaktadır. Kurumsal ve idari düzenlemeler, yürütülen çalışmaları etkileyen ve doğal olarak belge işlemlerini de belirleyen içeriğe sahiptir. Günümüzde belge yönetimi, kurumları yasal sorunlardan koruyan bir destek unsuru olarak da algılanmaktadır (Spratt, 2004, s.4). Kurumsal düzenlemelerdeki değişim doğal olarak belge işlemlerinde de paralel değişimleri gerekli kılmaktadır. Avrupa Birliği, Birleşmiş Milletler ya da Dünya Ticaret Örgütü türü oluşumların kabul ettiği yasal düzenlemeler, pek çok alanda uluslararası yükümlülükleri beraberinde getirmektedir. Bundan ötürü belge yönetimi alanında çalışmalar yürüten kişilerin, yerel düzenlemelerle birlikte uluslararası düzenlemeleri göz ardı etmesi mümkün görülmemektedir. Çalışmanın ilerleyen bölümlerinde ilgili düzenlemeler ele alınmaktadır. 
- Küresel Enformasyon Kaynağı Olarak Internet: İnternet'in günlük yaşamı derinden etkilediği görülmektedir. Bu durum kurumsal yaşam için daha sarsıcı boyutlara ulaşabilmektedir. Önceleri ulusal düzeyde hizmet üreten pek çok oluşum İnternet yoluyla çalışmalarını uluslararası boyuta taşımış ya da taşıma yolundadır. Uluslararası arenada hizmetlerini yürüten kurumların ağ bağlantıları olmadan, bu ortamı kullanarak iletişim faaliyetlerini yürütmeden var olması zorlaşmaktadır. Internet, küçük ölçekli organizasyonların dahi küresel olarak tanınması, ilgili organizasyon ya da kişilerle bilgi ve kaynak alışverişi yapabilmesi için inanılmaz olanaklar sunmaktadır (Stephens, 2001, s.68).

- Küresel İş ve Teknoloji Çözümleri: Genel olarak belge yönetimi konusunda iş ve teknoloji çözümlerinin 90'lı yıllara kadar gereksinimleri karşılamaktan uzak olduğu, bu tarihlerden itibaren ise pek çok ticari kuruluşun ilgili konuda programlar geliştirdiği bilinmektedir. ABD kökenli Iron Mountain, Avustralya kökenli Brambles ve Japon kökenli Canon ve Minolta şirketlerinin, küresel pazarda ticari belgelerin depolanması üzerine öncü kuruluşlar olduğu dile getirilmektedir. Belge yönetimi yazılımları üzerine Avustralya kökenli Tower Software'in pazarda öncü konumunda olduğu belirtilmektedir (Stephens, 2001, s.68). Özellikle son yıllarda teknolojik değişimler belge ve doküman yönetimi alanında önemli olanaklar yaratmıştır. Gerek kâğıt üzerindeki doküman ve belgelerin bilgisayar ortamına aktarılması ve hizmete sunulması, gerekse elektronik olarak belge üretim, düzenleme, saklama ve ayıklama işlemlerine yönelik programlara duyulan gereksinim, önemli bir pazarın oluşmasına yol açmıştır (Spratt, 2004, s.1; Stephens, 2001, s.68).

Tablo 1: Günümüzde Belge Yönetimini Etkileyen Unsurlar

\section{Belge Yönetimi Alanında Ortak Çalışmalara Yöneliş ve Uluslararası Uygulamalar}

Yeni teknolojiler, dinamik örgütlenmeler, küreselleşmenin ekonomik ve sosyal etkileri, iletişim alanındaki baş döndürücü gelişmeler, belge ve arşiv çalışmalarının geleneksel yaklaşımların ötesinde tanımlanmasını gerektiren radikal gelişmelere işaret etmektedir. Tüm bu unsurlar, organizasyonları sadece kurum içi yeniden yapılandırma çalışmalarına zorlamamakta, aynı zamanda uluslararası uygulamalar ve standartlara yönelişi gerektirmektedir (Duff ve McKemmish, 2000, s.4). Belge yönetimi alanında ortak çalışmalar beraberinde çeşitli avantajlar ve dezavantajlar da getirmektedir. Avantajlar;

Paylaşım yoluyla olanakların daha etkili olarak kullanımı,

> Aynı işe yönelik gereksiz iş gücü ve kaynak kullanımının ortadan kaldırılması,

> Deneyim ve gelişmelerin paylaşımı, 
Belge işlemlerinin daha merkezi ve profesyonel olarak gerçekleştirilmesi,

Politik ve ekonomik destek ile kamuoyu yaratma gücünün artışı gösterilebilir.

Dezavantajlar arasında ise:

> Ortak çalışmaların getirdiği bağımlılık,

$>\quad$ Farklı kurumların önceliklerine yönelik birlikte karar almanın güçlüğü,

Fiziksel mesafenin yarattığı sorunlar,

> Yasa ve uygulamaların yarattığı sınırlamalar sıralanabilir (Mims, 2004:49).

Belge yönetimi alanında ortak çalışmaların yarattığı olumlu etkiler yanında, birlikte çalışma kültürünün yarattığı olumsuz unsurların mutlaka göz önünde tutulması gerekmektedir.

Öte yandan uluslararası kuruluşlar üzerine gerçekleştirilen bir araştırma, bu alanda faaliyet gösteren kurumların bir yılda ürettikleri belge miktarının \%20 ile \%60 oranında artış gösterdiğini ortaya koymuştur (Stephens, 2005, s.29).

$\mathrm{Bu}$ araştırmada elde edilen bir diğer ilginç veri, kurumların veri yönetimi adı altında elektronik ve basılı belgeleri, yaşam döngüsü yaklaşımı çerçevesinde denetim altına almaya başlamasıdır.

Ancak bu durum iki farklı konunun gündeme girmesine yol açmaktadır. İlki birbirinden yapı ve işleyiş olarak farklı örgütlenen kurumların, hukuki ya da ticari ilişkilerinde nasıl bir ortak yapılanmaya gidecekleri; diğeri çoğu zaman tek başına bir kurumun geliştirmesi mümkün olmayan uygulama ve standartların, kim tarafından ve nasıl oluşturulacağı konusudur. Belge yönetimi alanında yaşanan bu sorunlara çözüm üretme noktasında, meslek dernekleri ve uluslararası kuruluşların çalışmaları ön plana çıkması gerekmektedir. 


\subsection{Belge Yönetimi Alanında Belli Başıı Dernekler ve Derneklerin Uluslararası Çalışmaları}

Belge ve arşiv çalışmalarının küreselleşmesi, uluslararası uygulamaların geliştirilmesi ve standartların oluşturulmasında, meslek derneklerinin önemli etkileri söz konusudur. Bu derneklerin bir kısmı bölgesel ya da ulusal nitelikte olmalarına karşın uluslararası çalışmalara da yönelirken, diğer bir kısmı oluşumları itibariyle uluslararası niteliği sahiptirler. Bu derneklerin uluslararası arenada belge yönetimin tanınması, benimsenmesi ve elektronik belge yönetimine dönük çalışmalarıyla, ulusal sınırları aşan oldukça kapsamlı uygulamaları söz konusudur (Bkz. Tablo 2). Aşağıda ilgili dernekler ve bu derneklerce uluslararası nitelikte yürütülen çalışmalara ilişkin örnekler sunulmaktadır.

Bilgi Yönetimi Derneği (ARMA; The Association for Information Management)

Belge Yöneticileri ve İarecileri Derneği (ARMA; Association of Records Managers and Administrators) olarak 1955 yılında kurulan dernek, faaliyetlerini 1975 yılından itibaren uluslararası boyuta taşınmış ve adını Bilgi Yönetimi Derneği (The Association for Information Management) olarak değiştirmiştir. ARMA, 1972 yılında Avustralya ve Filipinler ile birlikte oluşturduğu Uluslararası Belge Yönetimi Federasyonu (International Records Management Federation) ile uluslararası nitelikte çalışmalar yürütmeye başlamıştır (Benedon, 1999: 6). 80'li yılların sonlarına doğru derneğin uluslararası faaliyetleri yoğunlaşmış ve adını "ARMA International" olarak tekrar değiştirmiştir. Kanada, Japonya, Jamaica, Puerto Rico ve Yeni Zelanda birer şubesi bulunan ARMA, benzer nitelikteki ICA (International Council on Archives) ve IRMT (International Records Manegement Trust) ile koordineli çalışmalar da yürütmektedir. ARMA International ayrıca, ilk uluslararası belge yönetim standardı olan ISO 15489'un hazırlanmasında aktif rol almıştır (ARMA International, 2006; Stephens, 2001, s.68).

Enformasyon ve Imaj Yönetimi Derneği (AIIM, The Association for Information and Image Management)

AlıM'in 90'ı yıllara kadar daha çok mikrofilm teknolojileri üzerine odaklanmıştır ve her yıl düzenli olarak uluslararası mikrografi kongresini (International Micrographics Congress) düzenlemiştir. Dernek, ISO (The International Standardization for Organizations) çerçevesinde film tabanlı belgeler ile elektronik dokümanlara yönelik uluslararası standartlar geliştirilmesi üzerinde çalışmaktadır. Misyonu ve vizyonundaki değişimler sonucu, derneğin kısaltıımış ismi değişmezken, açık adı İçerik Yönetimi Girişimi (Enterprise Content Management) olarak yeniden tanımlanmıştır (Enterprise Content Management Association, 2006). 
Uluslararası Arşiv Konseyi (ICA, International Council on Archives)

1948 tarihinde Paris'te kuruluşundan itibaren çalışmalarını uluslararası boyutta yürütmeye başlamıştır. ICA şu anda 190 ülke ve bölgeyi içine alan 1400'ü aşkın üyeye sahip küresel bir arşiv organizasyonu konumundadır (International Council on Archives, 2006). Arşivcilik alanında kurulmuş bir örgüt olmasına karşın, güncel değere sahip belgelerin korunması üzerine çalışmaları ile uluslararası belge yönetimi konusunda oldukça önemli faaliyetler yürütmektedir. ICA içerisinde oluşturulan Elektronik ve Diğer Güncel Belgeler Komitesi (Committee on Electronic and Other Current Records) belge yönetimi alanında teknik rehberler ve uygulamalar geliştirmiştir.

Uluslararası Belge Yönetimi Vakfı (IRMT, International Records Management Trust)

1989'da kurulan Derneğin öncelikli amaçları arasında özellikle gelişmekte olan ülkelerde kamu kurumlarında belge yönetimi programlarının geliştirilmesi yer almaktadır. Dernek, Dünya Bankası ile birlikte Belge Yönetimi Kapasite Değerlendirme Sistemi (Records Management Capacity Assessment System)'ni 4 yıllık bir çalışmanın ürünü olarak meydana getirmiştir. Belge yönetimi programların geliştirilmesi ve değerlendirilmesinde yararlanılabilecek program ve ücretsiz yazılımı IRMT'nin web sayfasından temin edilebilmektedir. (International Records Management Trust, 2006). Vakfın önemli faaliyet alanları arasında belge yönetim programlarının geliştirilmesi ve var olan programların desteklenmesini bulunmaktadır (Stephens, 2001, s.68).

Prism International (Professional Records \& Information Services Management)

Oluşum özellikle, belge yönetimi ve belge sistemleri konusunda uzman ticari kuruluşlarla iletişime yönelik bir bağlantı noktası konumundadır. ABD'de çalışmalarını yoğunlaştırmakla birlikte, Avustralya, Hong Kong, İngiltere, İsveç ve Tayland gibi ülkelerde şubeleri bulunmaktadır (PRISM International, 2006; Stephens, 2001, s. 68).

Tablo 2: Belge Yönetimi Alanında Belli Başlı Dernekler

\subsection{Küresel Uyum Sürecinde Belge ve Arşiv Alanında Yasal Düzenlemeler}

Yönetim ve idari sistemlerdeki değişim, yeni uygulamalara dönük yasal düzenlemelerin geliştirilmesini gerektirmektedir. Uzun yıllar belge yönetimi uygulamaları belirli bir kurum, bölge ya da ulusal çerçevede düşünülmüştür. Ancak küreselleşen koşullarla bölgesel ya da ulusal sınırları aşan düzenlemelere duyulan gereksinim, beraberinde uluslararası etkileri olan yasal düzenlemelerin geliştirilmesine yol açmıştır. Böylece belge yönetimi alanında bölgesel etkileri olan düzenlemeler, uluslararası boyuta taşınmıştır.

Belge yönetimi alanında yasal düzenlemeler, sorunların sıklıkla yaşandığı alanlarda ön plana çıkmaktadır. "Dava Riskinde 
Kaçınma Girişimleri (Litigation Risk Avoidance Initiatives) olarak tanımlanan bu çabaların, özellikle ABD'de yoğunlaştığından söz edilmektedir. ABD'de belge koruma ve belge saklama işlemleri ile ilgili yaptırımlar içeren yaklaşık 10.000 ile 20.000 arasında yasal düzenlemenin olduğu ve işlemlerinin nasıl yürütüleceği konusunda oldukça sıkıntıların yaşandığı söylenmektedir (Stephens, 2001, s.66). Öte yandan küresel anlamda ortaklıklar kurumları, bölgeleri ve ülkeleri birlikte hareket etme noktasında benzer düzenlemeler yapmaya itmektedir. Birbirleriyle iletişim halinde olan farklı yapıdaki örgütler, kurumsal iletişim ve doğrulama eylemlerinin resmi yönünü oluşturan belgelerin yönetimi konusunda daha sade, anlaşlır ve ortak bir dile gereksinim duymaktadırlar. Örneğin Avrupa Birliği müktesebatı çerçevesinde çıkarılan yasal düzenlemeler, eşgüdümlü uygulamaları ve ortak bir dili geliştirmeyi amaçlamaktadır. AB özellikle 90'ı yıllarla birlikte belge iletişimi ve belge işlemlerinde yeknesaklığı sağlamak üzere bir dizi talimat yayımlamıştır. Bu talimatlar belge iletişimi, koruma ve saklama çalışmalarında uyulması gererken ilkeleri ortaya koymuştur (Stephens, 2001, s.66). Belge işlemlerinde yasal sorun yaşanmaması için kurumsal iş ve işlemleri etkileyen tüm unsurların göz önüne alınması ve bu çerçevede saklama koşullarının yerine getirilmesi gerekmektedir. McFarland (2005, s.69) ABD'de Enron Skandalı soruşturmasındaki en ağır cezalardan birinin nedeni olarak kayıtların yasal saklanma dönemlerinden önce imha edilmesini bu duruma örnek göstermektedir.

Belge yönetimi alanını doğrudan etkileyen küresel düzenlemelerin önemli bir bölümü Birleşmiş Milletler tarafından çıkartılmaktadır. Bu nedenle Birleşmiş Milletler çerçevesinde yürütülen çalışmaların ayrıca ele alınmasında yarar görülmektedir.

\section{Birleşmiş Milletler Çerçevesinde Geliştirilen Yasal Düzenlemeler}

Küresel e-ticaretin gelişimi karşısında Birleşmiş Milletler tarafından 1996 yılında Uluslararası Ticaret Komisyonu (United Nations Commission on International Trade Law) kurulmuştur. Komisyon, sayısal ortamlarda yer alan belgelerin korunmasına yönelik ilk uluslararası düzenlemeyi hazırlamış ve 1998 yılında yayımlamıştır.

Birleşik Elektronik Delil Yasası (Uniform Electronic Evidence Act) olarak bilinen düzenleme, $A B D$ dâhil olmak üzere pek çok 
ülke tarafından uyarlanmıştır. Düzenlemenin temel hedefleri arasında, ülkelerin belge koruma konusunda ulusal çalışmalarında eşgüdümün sağlanması ve teknolojik gelişmelere paralel sayısal ortama taşınan ilişkilerin koşullarının tanımlanması yer almaktadır.

E-ticaretin yaygınlaşmasına paralel elektronik ortamda belgelerin özgünlüğü, sayısal imza, belgelerin saklama koşulları ve süresi gibi konular, geliştirilen düzenleme kapsamında ele alınmaktadır (Stephens, 2001, s.67; United Nations, 1998).

Düzenleme genel olarak belgelerin özgünlüğü, güvenilirliği ve kanıt niteliğini tanımlamaya yönelmektedir. Metin içerisinde elektronik belge; "herhangi bir bilgisayar sistemi ya da benzer araç tarafından üretilen ya da bu ortamlarda yer alan kaydedilmiş ya da depolanmış veri” olarak tanımlanmıştır. Belgenin elektronik olması bu ortamlarda üretilmesi ya da depolanmasından kaynaklanmakta, manyetik ya da "smart" kartlar üzerindeki verileri kapsamaktadır. Ancak faks ya da teleks bilgileri ile dijital telefon konuşmaları ve sesli mesajlar (voice mail) eğer elektronik ortamda değilse kapsam dışı kalmaktadır. Aynı şekilde elektronik ortama veya herhangi bir Web sayfasına taşınmamışsa, video kayıtları düzenleme kapsamında değerlendirilmemektedir (Spratt, 2004, s.8; United Nations, 1998).

Günümüzde çok uluslu kurumlar, kâğıda dayalı belge korumadan, sayısal ortamda belge koruma anlayışına doğru hızlı bir geçiş yapma zorunluluğuyla karşı karşıyadır. Bu geçişin uzman belge yöneticilerinden yoksun olarak gerçekleştirilmesi mümkün değildir. Yukarıda dile getirilen yasal düzenlemenin, e-ticaret ve ebelge yönetimi gereksinimlerini karşılayabilecek nitelikte olduğu görülmektedir.

Birleşmiş Milletler Uluslararası Ticaret Komisyonu (UN Commission on International Trade) tarafından 1996 yılında geliştirilen bir diğer düzenleme, Birleşmiş Milletler Elektronik Ticaret Model Yasasıdır (United Nations Model Law on Electronic Commerce). Bu yasa, e-ticaretin giderek yaygınlaşması üzerine, üye ülkelerin kendi aralarında ya da ulusal düzeyde gerçekleştirdikleri ticari iş ve işlemlerde uygulanacak yasal koşulları belirlemek amacıyla geliştirmiştir. Genel olarak kâğıda dayalı ortamların yerini alan elektronik ortamdaki ticari ilişkileri 
tanımlamayan yasa, ülkelerin kendi e-ticaret yasalarını çıkarmalarına model olmayı amaçlamıştır (Spratt, 2004, s.8; United Nations, 1996).

\subsection{Elektronik Belge Yönetimi Uygulamaları}

Elektronik belge yönetimi giderek önemini artırmaktadır. Örneğin ABD'de yapılan bir araştırmaya göre, kamu kesiminde üretilen belgelerin yarıdan fazlasının artık elektronik ortamda üretildiği ya da saklandığı saptanmıştır.

Benzer örnekler $A B$ için de verilmektedir. Belgelerin elektronik ortada saklanması ve erişimi, belgelerin sadece belge formlarının değil bilgi içeriklerinin korunması ve erişimi için de önemlidir. Basılı belgeler üzerine hizmet geliştiren arşivler, ilke olarak belgelerin içeriğinin değil, formlarının korunması ve erişimine yönelik politikalar oluşturmuşlardır. Ancak elektronik ortamda üretilen ya da bu ortama aktarılan belgeler, kullanıcılarına içeriğe bağlı çok yönlü erişim olanağı sunmaktadır (MacKenzie, 1999, s.29; Sprehe, 2005 , s.24). Bu saptamalarla birlikte, henüz e-belge yönetimine dönük geliştirilen uygulamaların gereksinimleri karşılamaktan uzak olduğu dile getirilmektedir. Elektronik belge yönetimi çalışmalarının genelde ulusal arşivler tarafından yürütüldüğü ya da desteklendiği görülmektedir. Özellikle ABD, Avustralya, İngiltere ve Kanada ulusal arşivlerinin çalışmaları dikkat çekmektedir. Buna karşın yukarıda değinilen ulusal arşivlerin ortak ya da benzer belge yönetim geleneğinden geldiği ve e-belge yönetime dönük uygulamaların da büyük ölçüde birbirleri ile örtüştüğü bilinmektedir (MacKenzie, 1999, s.29; Sprehe, 2005, s.24).

ABD'de elektronik belge yönetimi politikalarının belirlenmesine yönelik ilk çalışma, 1997 yılında Federal Bölge Mahkemesinin aldığı bir karara dayandırılmaktadır. Kararda kullanılan "Genel Belge Şeması 20" (Generel Records Schudle GRS 20)'nın güncel gereksinimleri karşılayamadığı ortaya konulmuştur. Bunun üzerine 1998 yılında özellikle ABD Ulusal Arşivi-NARA ve Amerikan Savunma Bakanlığının ortak girişimleriyle, Elektronik Belge Yönetim Yazılım Uygulamalarının Tasarım Kriterleri 5015.2 hazırlanmıştır (DoD 2002; MacKenzie, 1999, s.29). 
Avustralya'da Ulusal Arşiv tarafından elektronik belge korumaya yönelik birçok doküman yayımlamıştır. Bunların önemli bir kısmı Avustralya Ulusal Belge Yönetim Standardı (AS 4390) çerçevesinde hazırlanmıştır (MacKenzie, 1999, s.30; National..., 2006).

İngiltere'de ise, İngiliz Ulusal Arşivince elektronik veri içeren istatistik ya da ekonomi (örneğin araştırma veri tabanları) kaynaklarına yönelik Londra Üniversitesi ile birlikte Ofis Sistemlerinde Elektronik Belgeler adlı bir program geliştirilmiştir. İngiliz Ulusal Arşivi 1999 yılında "Elektronik Belge Yönetim Sistemleri İçin İşlevsel Gereksinimleri (Functional Requirements for Electronic Records Management Systems)" yayımlamıştır. 2002 yılında gözden geçirilen rehberde, özellikle; belge yönetim programlarının geliştirilmesinde izlenecek yöntemler, belgelerin tanımlanmasında kullanılabilecek örnek üst veri unsurları, dosyalama uygulamaların geliştirilmesine dönük yöntemler ve güncel olmayan belgelerin transferine ilişkin ayrıntılı bilgiler yer almaktadır (National Archives of Unites Kingdom, 2002).

Kanada'da elektronik belgelere yönelik rehberler, diğer ülkelerde olduğu gibi Kanada Ulusal Arşivi tarafından yayımlamaktadır. Özellikle 25 kamu kurumunun katılımıyla Ulusal Arşiv tarafından oluşturulan Bilgi Yönetimi Formu (Information Management Form), pek çok alanda olduğu gibi e-belge yönetimi konusunda çeşitli rehberler ve dokümanlar hazırlamıştır (Information Use Management and Policy Institute, 2006).

Elektronik belge yönetimi konusunda pek çok ortak çalışma grubu oluşturulmuştur. Bu grupların en önemlilerinden biri, Kanada'da British Colombia Üniversitesinden Profesör Luciana Duranti tarafından 1999 tarihinde başlatılan ve 3 yıl sonra hayata geçen "INTERPARES" Girişimi (Eşitler arasında anlamına geliyor. Açık adı "Elektronik Sistemlerde Kalıcı Otantik Belgeler Üzerine Uluslararası Araştırma" (International Research on Permanent Authentic Records in Electronic Systems)'dır. Girişimin amaçları; arşiv alanında uygulamalar geliştirme, elektronik ortamda belgelerin uzun dönemler için korunması ve kullanımını sağlama, politikalar, stratejiler ve standartlar oluşturma olarak özetlenmektedir. Girişim, bilgi teknolojisi endüstrisinden 
uzmanların katıımı ile ABD, Avustralya, Kanada, İtalya ve çeşitli Avrupa Birliği ülkeleri ile bölgesel girişimleri bünyesinde toplamıştır (INTERPARES, 2006; MacKenzie, 1999, s.30).

\section{Belge ve Arşiv Yönetimi Alanında Standartlaşma Çalışmaları}

Belge yönetimi alanında standartların geliştirilmesi ve genel geçerliliği olan bir belge yönetimi uygulama rehberinin benimsenmesi üzerinde, 90 'lı yıllara kadar uzlaşıya varılamadığına değinilmektedir (Stephens, 2001, s.7). Bu dönemden sonra geliştirilen standartlar ile belge yönetimine dönük uluslararası standartların ve uygulama rehberlerinin ortaya çıkması, bir taraftan alanın gelişimini ve geniş kesimlerce tanınmasını beraberinde getirirken, uygulamada karşılaşılan sorunların aşılabilmesinde büyük bir boşluğu doldurmuştur. Standartlar, belge yönetimi alanında düzenlemeler geliştirmede iki yönden etkili olmaktadırlar. Bunlardan ilki, kurumda belge yönetimi uzmanı olmayıp belge işlemlerini yürüten ya da sorumlu olan kişilere yönelik çalışma akışı ve işleyiş biçimini ortaya koymak için standartlardan yararlanmak, diğeri uygulamaların gerek kurum içi, gerek bölgesel ve ulusal gerekse uluslararası olarak çok daha geniş alanlarda uyumlu ve eşgüdümlü yürütülebilmesini sağlamaktır (Gringrich, 2006, s.31).

Arşivcilik alanında, özellikle son 50 yıllık geçmişte, kütüphanelikte kataloglamaya benzer bibliyografik tanımlama sistemleri geliştirilmeye çalışılmıştır. Örneğin Kanada Arşivistler Bürosu (Brueau of Canadian Archivists) 1990 yılında yayımladığı Arşivsel Tanımlama Kuralları (Rules for Archival Description, $R A D$ ), Anglo Amerikan Kataloglama Kuralları 2 (AACR2) temel alınarak geliştirilmiştir. AACR2 ve MARC (Machine Readable Cataloguing)'ın arşiv kaynaklarının tanımlanmasında yetersiz olduğunu gören Amerikalı arşivistler Staven Jense'nin öncülüğünde, 1989 yılında arşiv kaynakları için yeni alanların tanımlanması için çalışmaya başlamışlardır.

Sonuçta, Amerikan Arşivistler Derneği (Society of American Archivists) tarafından AACR2'ye arşiv materyallerinin uyarlanması ile Arşivler, Kişisel Belgeler ve El Yazmaları (Archives, Personel Papers and Manuscripts, APPM) adlı standart geliştirilmiştir (Shepherd ve West, 2002, s.18). İngiltere'de arşiv malzemelerinin 
tanımlanmasına yönelik ilk standart ise, arşiv deneyimlerinin bir ürünü olarak hazırlanan ve 1986 yılında yayımlanan Arşivsel Tanımlama El Kitabı (Manual for the Archival Description, MAD) olmuştur (The Society of American Archivists, 1999).

Bahsedilen standartlaşma çalışmaları, belirli kurum ya da alanların dışında genel geçer uygulamalara dönüşememiş ve bu durum 2000'li yıllara kadar etkisini devam ettirmiştir. Örneğin 1997 yılında İngiltere'de 128 kurum üzerine yapılan bir araştırmada, bunların \%60'ının kendi gereksinimlerine göre geliştirdikleri tanımlama ölçütlerini uyguladığı, ancak \%5,4'ünün ulusal ya da uluslararası nitelikte (ISAD(G) gibi) standartları benimsediği saptanmıştır (Shepherd ve West, 2002, s.18).

Günümüzde, kültürel mirasın parçası niteliğindeki arşivler, kütüphaneler ve müzelerde yer alan materyallere yönelik bütünleşik tanımlama, erişim ve koruma standartlarının geliştirilmesi çalışmalarına devam edilmektedir. Gerek arşivler, gerek kütüphane ve müzelerdeki eserlerin ortak bir bilgi havuzunda tanımlanmasına yönelik çeşitli projeler yürütülmektedir. Projelerin amaçları arasında, üç tür bilgi merkezinde yer alan kaynakların erişimine yönelik, standart tanımlama sistemlerinin geliştirilmesi de bulunmaktadır. Günümüzde arşiv belgelerinin tanımlanmasında kullanılan en yaygın standart ISAD(G)'dir. Müze materyallerinin tanımlama standardı olarak da, İngiltere'de Müze Dokümantasyon Derneği (Museum Documentation Association) tarafından geliştirilen SPECTRUM örnek gösterilmektedir (Shepherd ve West, 2002, s.17). Kütüphanecikte tanımlama standartlarının (AACR2 ve MARC gibi) geliştirilmesinin, kitap ve süreli yayın türü kaynakların doğası gereği, organik bir iş sürecinin uzantısı olarak ortaya çıkan arşiv materyallerine göre daha rahat olduğu kuşku götürmez bir gerçektir. Öte yandan, bilgi kaynağı olarak kütüphane ve arşiv materyalleri ile müze materyallerinin ortak erişimine dönük çalışmaların, son derece dikkatli ele alınması gerekmektedir. Farklı türden materyalleri aynı sistem içerisinde tanımlamak yerine, kullanılan sistemlerin ortak erişimine dönük bütünleşik projelerin yürütülmesi daha akılcı bulunmaktadır. Belge yönetimi alanında 90'ların sonlarıyla birlikte, farklı materyalleri de içine alacak biçimde bütünleşik çalışmaların yürütülmesine dönük olanaklar artmıştır. Yazılım ve donanım 
olanaklarının gelişmesi, bilgi ve belge kaynaklarının üretimi ve erişimini ve depolanması kolaylaştırmıştır.

Böylece elektronik ortamda belge ve arşiv kaynaklarının tanımlamasına yönelik koşullar olgunlaşmıştır.

\subsection{ISO 9000: Kalite Belgeleri İçin Standart}

Kalite güvence standartları içerisinde, belirli bir alana değil genele hitap eden ilk uluslararası standart, ISO 9000 "Kalite Yönetimi Sistemleri Standardı" olmuştur. ISO (International Organization for Standardization; Uluslararası Standartlar Örgütü) Kalite Yönetimi Sistemleri Standardının kökeni, 1979 yılında oluşturulan 176 sayılı Teknik Komite'ye dayandırımaktadır (ISO/TC176). Komite başlangıç olarak, üretim sektöründe yer alan kuruluşların, kalite kontrol yöntemlerini uygulayabilmeleri için gerekli olan uluslararası asgari ölçüleri belirlemeyi amaçlamıştır. Teknik Komite çalışmaları; 1987 yılında 20 aktif ve 10 gözlemci ülkenin gözetiminde, "ISO 9000 Kalite Yönetim Sistemi Standartları"nın ortaya çıkışını sağlamıştır (Bozkurt 1999:13; ISO...2006). İlk olarak 1987 yılında yayımlanan ve 1994 ve 2000 yıllarında gözden geçirilerek tekrar basılan ISO standartları, 1988 tarihinde Avrupa Birliği tarafından kabul edilerek EN 29000 Standartları olarak yayımlanmıştır (Bozkurt, 1999, s.13; European Committee for Standardization, 2004, s.1).

ISO 9000'in öngördüğü kalite modeli, kurumsal yapıyı sistem olgusu içerisinde ele almakta ve öncelikle bir kalite sisteminin oluşturulmasını gerektirmektedir. Bu yapıda yönetim işlevleri kişilerden çok sistemlere dayalı olarak yürütülmektedir. Kalite sistemi içerisinde kurumsal iş ve işlemlerin tanımlanması, geliştirilen teknikler ve standartlar çerçevesinde analiz edilmesi, değerlendirilmesi ve yeniden yorumlanarak programların geliştirilmesi öngörülmektedir (Aytimur, 1997, ss.29-60; TS EN ISO $9001,2001)$. Kalite sistem dokümantasyonu olarak adlandırılan bu çalışmaların (Schlickman, 2003, s.11; TS EN ISO 9001, 2001, ss.4-5) gerçekleştirilebilmesi için, kurumsal iş ve işlemlerin bir parçası konumundaki belgelere yönelik etkin bir sistemin varlığı önemlidir. Var olan koşullarda ilk elden, doğru bilgiyi sağlayan belgeler, kurumsal kararları etkileyebilmekte ya da belirleyebilmektedir. Bu çerçevede kaliteye dayalı sistemlerde 
belgeler, kaliteye giden yolda doğru bilgiye erişimi sağlayan araçlar, belge yönetimi ise araçların etkin yönetimi olarak tanımlanmaktadır (Duff ve McKemmish, 2000, s.1; Külcü, 2005). Ayrıca ISO 9000 dışında ISO tarafından yayımlanan ve doğrudan belge işlemlerini etkileyen aşağıdaki düzenlemelerin de dikkatle incelenmesinde yarar vardır:

$>$ ISO International Standards 11179-3, Information Technology - Metadata Registers - Part 3: Registry Metamodel and Basic Attributes, 2nd Edition, 2003: 02-15

ISO Technical Report 20943-1, Information TechnologyProcedures for Achieving Metadata Registry (MDR) Content Consistency - Part 1: Data Elements, 2003-08-01

> ISO Technical Report 20943-3, Information Technology Procedures for Achieving Metadata Registry (MDR) Content Consistency - Part 1: Value Domains, 2004-03-01

$>$ ISO Technical Specification 23081 (Zeaman ve Healey, 2005, s.142).

ISO/IEC 17799, Information Technology- Security Techniques- Code of Practice (Fanning, 2005, s.61).

\subsection{Avustralya Ulusal Belge Yönetim Standardı (AS 4390)}

Avustralya Ulusal Arşivi tarafından geliştirilen AS 4390 kodlu belge yönetimi standardı, uluslararası belge yönetimi standardının geliştirilmesinde temel alındığından ayrı olarak incelenmesi gerekli görülmektedir. Belge yönetimi alanında ulusal boyutta kabul edilen ilk standart olan Avustralya Belge Yönetimi Standardı (Australian National Standard for Records Management) ulusal sınırların ötesinde çok daha geniş bir alanda etkili olmuştur. Standart, çoğunluğu kamu kesiminden gelen arşiv ve belge profesyonelleri ile özel sektör danışmanları, kurumları ve Avustralya Kurum Sekreteryaları Enstitüsü (Institute of Company Secretaries of Australia)'nün girişimleri sonucu 1996 yılında kabul edilmiştir. AS 4390 Standardının geliştirilmesine yönelik girişimler, geleneksel veya elektronik ortamda üretilen ve kullanılan belgelerin kodlama standartlarının oluşturulması amacıyla başlatımıştır. Ancak standardın ası önemi, kurumsal belge yönetimi uygulamalarını bir 
bütün olarak ele alarak, tasarımdan nihai ayıklamaya kadar ayrıntılarıyla tanımlaması ve belge yönetimi alanında dünyanın ilk genel standardı olarak kabul edilmesinde yatmaktadır (Stephens, 2001, s.70; National Archives of Australia, 2006). Standart genel olarak şu amaçlara yöneliktir:

a. Belge hizmetlerinin yürütüldüğü kurumsal çevrenin analizi,

b. Belge işlemlerinin de dâhil dolduğu iş sürecinin analizi,

c. Hangi belgelerin sağlanacağı, ne kadar süre alıkonulacağına karar vermeye yönelik entellektüel çalışmalar (MacKenzie, 1999, s.26).

ISO'nun 1998 yılında Atina'da gerçekleştiren 46 Nolu Teknik Komite toplantısına ABD, Almanya, Avustralya, Danimarka, Fransa, İngiltere, İrlanda, İsveç, Kanada ülke temsilcileri ile ARMA, ICA ve IRMC'nin heyetleri katılmıştır.

Bu komite, ISO'nun belge yönetimi alanında oluşturduğu ve 2001 yılında yayımlanan uluslararası nitelikteki ISO 15489 belge yönetimi standardını geliştirilirken AS 4390 standardını temel almıştır (MacKenzie, 1999, s.28).

\subsection{ISO 15489 Uluslararası Belge Yönetim Standardı}

ISO'nun Bilgi ve Dokümantasyon Teknik Komitesi'ne (Information and Documentation ISO/TC 46) bağlı Arşiv ve Belge Yönetimi Alt Komitesi (Archive and Records Management, SC 11), 2001 yılında ISO 15489-1 kodlu "Uluslararası Belge Yönetim Standardını" geliştirmiş ve ISO /TR 15489-2 kodlu Teknik Raporu yayımlamıştır.

ISO 15489, ISO ve çeşitli belge yönetimi örgütlerinin ortak çalışmaları sonucu geliştirilen, belge yönetimine dönük küresel ilk standarttır. ISO 15489, ISO'nun belge yönetim standardı olarak tüm kurumlara yönelik genel içerikli tanımlamalara yer vermektedir. Belge yönetimini kurumsal yönetimin vazgeçilmez bir uygulama alanı olarak tanımlaması, diğer yönetsel disiplinlerle belge yönetimi arasındaki ilişkinin ortaya konulması ve kurumsal kalite ve verimlilik ile belge yönetimi arasında organik yakınlaşmanın kurulması, ISO 15489'un ön plana çıkan unsurları arasındadır (Chain, 2002, s.16; Stephens, 2001, s.70). 
ISO 15489 genel olarak, kurumsal belge sistemlerinin tasarımı ve uygulanması, belge yönetimi çalışmalarının gerçekleştirilmesi, kontrolü, gözden geçirilmesi ve eğitimi üzerine programların, politikaların ve sorumlulukların tanımlandığı düzenlemelerden oluşmaktadır (Stepherd, 2003, s.9). Standart genel olarak iki bölümde değerlendirilmektedir:

$>\quad$ ISO 15489-1: Bilgi ve Dokümantasyon - Belge Yönetimi Bölüm 1: Genel içerikli standartta yer alan unsurlar tanımlanmaktadır.

ISO 15489-2: Bilgi ve Dokümantasyon - Belge Yönetimi Bölüm 2: Rehber. Standarttan çok teknik rapor olmasına karşın, standardın uygulama boyutunu ortaya koymaktadır (Connelly, 2001: 26; ISO 15489-1/2 2001).

2001 yılının ilk aylarında ISO standartlar serisi içerisinde yayımlanan ISO 15489 Bilgi ve Dokümantasyon- Belge Yönetimi Standardı, yaklaşık 80 ülkenin aktif ya da pasif katılımları ve destekleri ile yayımlanmıştır. Kurumların yapısı, boyutu ve çalışma alanlarına bakmaksızın, uygulamaları gerekli görülen asgari belge yönetim unsurlarını tanımlayan standart, belge programlarının nasıl oluşturulacağı, nasıl yapılanacağı ve kontrol sistemlerinin ne şekilde organize edileceğini ortaya koymaktadır. ISO 15489, ISO'nun geliştirdiği genel standartlar olan ISO 9000 ve ISO 14000 ile uyumlu, üzerinden kurumsal, bölgesel ve ulusal belge yönetim uygulamalarının oluşturulmasına elverişli bir yapıya sahiptir.

Yaklaşık 50 yıllık süreçte ABD, Avustralya, İngiltere ve Kanada başta olmak üzere belge yönetimi alanında standartlar geliştirmeye yönelen tüm ülkeler, ISO 15489 çerçevesinde belge işlemlerinin tanımlanması noktasında uzlaşıya varmış görülmektedirler (Connelly, 2001, s.26). Standart geliştirilirken ülke ve kurum delegelerinin farklı önerilerde bulunduğuna, ortak bir metinde uzlaşabilmek için standart içerisinde genel ifadelere ağırlıklı olarak yer verildiğine değinilmektedir. Örneğin Standardın oluşumu aşamasında, Yeni Zelanda delegelerinin arşiv çalışmalarının tanımlanmasını istediği, Almanya delegelerinin ise, belge saklama dönemlerinin ayrıntılarıyla belirtilmesi yönünde görüş bildirdikleri ifade edilmektedir. Ancak her ülkede belge ve arşiv çalışmalarını ve bunlara ait yasal düzenlemelerin farklılıklar göstermesi 
nedeniyle, bu tür ayrıntılara standart içerisinde yer verilmediği dile getirilmektedir (Connelly, 2001, s.27).

Standart "genel" başlığı altında belge yönetimini tanımlanmakta ve ilgili terimlere açıklama getirilmekte, belge yönetiminin yararları, kurumsal yasa ve uygulamalarla ilişkisi vurgulamaktadır. "Politikalar ve Sorumluluklar" başlığı altında, kurumsal belge yönetimine ilişkin politikaların, düzenlemelerin ve uygulamaların tanımlanması, bunların yazılı hale getirilmesi ve belge yönetim sisteminin yazılanlar çerçevesinde yürütülmesi ve denetimi gerektiği dile getirilmektedir. Standardın 7. bölümü belge yönetim gereksinimlerine ayrılmıştır. Belge yönetimi gereksinimleri içerisinde kurumsal, yasal ve idari analizin yapılması, belge yönetimi ve belge yönetim unsurlarına yönelik gerekli dokümantasyonun, elde edilen bilgiler doğrultusunda gerçekleşmesi öngörülmektedir (ISO 15489-1, 2001, s.6). Standardın 8.3.7. bölümü ise, belge saklama ve ayıklama üzerine açıklamaları içermektedir. Açıklamalara göre kurumsal belge sistemi, belgelerin alıkonması ve ayıklanması için gerekli verileri sağlayacak, kolaylaştıracak özelliklere sahip olmalıdır. Bölümde, belgelerin alıkonması ve ayıklanması için doğru zamanlama ve etkin karar vermeye yönelik bir sistemin oluşturulması ve bu sistemin sürekliliğinin sağlanması üzerinde durulmaktadır. Yine 8.4. bölümde dile getirilen etkin belge sisteminin tasarımına yönelik ön araştırma, iş aktivitelerinin analizi, belge gereksinimlerinin tanımlanması ve mevcut sistemin değerlendirilmesi gerektiği vurgulanmaktadır (ISO 15489-1, 2001, ss.9-10). Standardın 9.2. bölümü, belgelerin ne kadar elde bulundurulacağının saptanması üzerine açıklamaları içermekte, elde bulundurulacak süreye karar vermek için yasal koşulların değerlendirilmesi, iş ve sorumluluklara yönelik gereksinimlerin saptanması ve risklerin öngörülmesi üzerinde durulmaktadır. Tüm bu çalışmalar sonucu ortaya çıkan bilgilerin, politikalara ya da standartlara dönüştürülmesi ve uygulamaların bu çerçevede gerçekleşmesi istenmektedir (ISO 15489-1, 2001, s.11).

Geliştirilen uluslararası standart çerçevesinde hazırlanan Rehber ise, yukarıda dile getirilen unsurların, daha iyi anlaşılması için gerekli açıklamaları içermektedir (ISO 15489-2, 2001, ss.1-24). $\mathrm{Bu}$ bağlamda geliştirilen uluslararası standardın belge yönetimi 
uygulamalarının daha geniş kesimlerce benimsenmesine katkı sağlayacağı ve kurumsal yönetimin bir unsuru ve çalışma alanı olarak kabul edilmesi sürecini hızlandıracağı düşünülmektedir. Böylece, kalite sistemlerine geçmeye ve kalite belgesi almaya yönelen kurumlar, uygulamaya geçirmeleri gereken belge yönetimi çalışmalarına yönelik temel bilgileri ve gereklilikleri, Standart ve Standart çerçevesinde hazırlanmış olan rehberden sağlayabileceklerdir. Standartta özetle aşağıdaki unsurlar üzerinde durulmaktadır:

a. Her bir iş süreci için belge gereksinimlerini belirleme,

b. Belge ve ilgili belge araçlarını tanımlama,

c. Gerekli üst veri unsurlarını oluşturma,

d. Belge erişim ve yayımına yönelik sistemler geliştirme,

e. Risk yönetimi,

f. Belge korumaya yönelik unsurlar,

g. Belge güvenliği,

h. Belge saklamaya yönelik unsurlar (Connelly, 2001, s.28).

2.4. DoD 5015.2 (The U.S. Department of Defense's Design Criteria Standard for Electronic Records Management Software Applications; ABD Savunma Bakanlığı Elektronik Belge Yönetimi Yazılım Uygulamaları İçin Standart)

Amerikan Savunma Bakanlığı, 90'lı yılların başından itibaren elektronik belge yönetimi ile ilgili yazılımlar hazırlamaya yönelmiştir. Bu süreçte yazılım programları geliştirilirken ilgili alanda standartların eksikliği ön plana çıkmış ve yazılım uygulamaları için standart oluşturmaya çalışmaları başlatılmıştır.

Standardın geliştirilmesi süreci, 1993 yılında ABD Ulusal Arşivi NARA (National Archives and Records Administration), ABD Ordusu ve Hava Kuvvetleri ile Ordu Araştırma Laboratuarları'nın bir araya gelerek DoD Belge Yönetimi Çalışma Grubunu (Records Management Task Force) oluşturmasına dayanmaktadır. Standardın teorik altyapısının ve özellikle elektronik belgelerin güvenilirliği ve otantikliği üzerine yaklaşımlar, British Colombia Üniversitesi ile Pittsburgh Üniversitesinde geliştirilmiştir (Gable, 2002, s.33). Çalışma Grubu 1995 yılında, Belge Yönetimi Uygulama Yazılımları İçin Veri Unsurları ve İşlevsel Temel Gereksinimler (Functional Baseline Requirements and Data 
Elements for Records Management Application Software) adlı bir rapor yayımlamıştır.

Çeşitli federal kuruluşlar ile ilgili konuda yazılım üreten kurumlara gönderilen rapor, gelen öneriler de dikkate alınarak 47 temel kriterden oluşan bugünkü konumunu almıştır (Gable, 2002, s.33) DoD 5015.2 Elektronik Belge Yönetim Yazılım Uygulamaları İçin Standart, Amerikan Ulusal Arşivi NARA'nın katkılarıyla geliştirilerek 1997 yılında yayımlanmıştır (Chain, 2002, s.16; DoD 5015.2, 2002).

DoD 5015.2 ABD Savunma Bakanlığı ve NARA tarafından belirlenen asgari belge ve arşiv yönetimi gereksinimlerini ortaya koymaktadır. Amerikan Savunma Bakanlığı Enformasyon Dairesi (U.S. Defense Information System Agency) tarafından geliştirilmesine karşın, tüm kurumsal yapılara uyumlu bir içerikte hazırlandığı dile getirilmektedir. Standart pek çok kamu ve özel kurum ile uluslararası kuruluş tarafından, belge yönetim yazılımlarını sağlama aşamasında etkin olarak kullanılmaktadır (Spratt, 2004, s.6).

Standardın yayımlanmasından kısa bir süre sonra geniş bir kullanım alanı bulmuş, ABD Ulusal Arşivi tarafından onaylanan ve dünyada kabul gören kendi alanındaki ilk standarttır. Özel sektör ya da kamu kesiminde belge yönetimi yazılımları sağlanırken, Standartta belirtilen unsurların temel alındığına değinilmektedir. Yine İngiliz Ulusal Arşivi (British Public Records Office) ve Avrupa Birliği tarafından geliştirilen MoReq (Model Requirements for Electronic Records Management; Elektronik Belge Yönetimi Model Gereksinimi) içerisindeki ilkeler DoD 5015.2 temel alınarak oluşturulmuştur (Gable, 2002, s.32).

Standart, özellikle elektronik belge yönetimi uygulamalarının tasarım aşamasında, uyulması gereken ölçütleri ortaya koyması bakımından önemlidir (Archives and Records Assocaition of New Zelland, 2004, s.1). DoD 5015.2 kodu ile 57 sayfa olarak yayımlanan Standart. ABD dışında İngiltere ve diğer bazı ülkelerce de kabul edilmiştir (DoD 5015.2, 2002; Stephens, 2001, s.70).

DoD 5015.2 standardı içerisinde yer alan tanımlar ve gereksinimler 2002 yılında gözden geçirilmiş ve çeşitli eklemeler 
yapılmıştır. Standart içerisinde yer alan ve Standardın II. Bölümünü oluşturan, belge yönetimi uygulamaları için gerekli unsurlar Tablo 3'de verilmektedir. Standardın I. Bölümünde giriş ve tanımlama, III. Bölümünde zorunlu olmayan unsurlara, IV. Bölümde ise "Sınıflanmış Belge Yönetim" altında uygulamalar verilmiştir (DoD 5015.2, 2002).

\begin{tabular}{|c|c|c|c|}
\hline \multicolumn{4}{|c|}{ DoD 5015.2 Gereklilikler Alt Bölüm Sayısı } \\
\hline \multirow[t]{5}{*}{ C.2.1 } & 1 & $\begin{array}{l}\text { Depolama ortamına bakılmaksızın tüm belgelerin aynı } \\
\text { sistem içerisinde tanımlanması }\end{array}$ & 0 \\
\hline & 2 & Dört basamaklı tarihlemeye göre yerleşim & 0 \\
\hline & 3 & Tanımlanmış kullanıcı ve değişiklik alanları oluşturma & 0 \\
\hline & 4 & Önceki uygulamalarla sisteme uyumunu sağlama & 0 \\
\hline & 5 & $\begin{array}{l}\text { İlgili yasal düzenlemelerle } \\
\text { karşılaştıııması }\end{array}$ & 0 \\
\hline \multirow[t]{8}{*}{ C.2.2 } & 1 & $\begin{array}{l}\text { Dosya planlarının uygulanması-Standart dosya planı } \\
\text { ve gerekli belge dosya unsurlarını belirlenmesi }\end{array}$ & 6 \\
\hline & 2 & Belge şemaları geliştirme & 7 \\
\hline & 3 & $\begin{array}{l}\text { Bildirim (declaring) ve dosyalama belgeleri- standartlar } \\
\text { ve gerekli üst veri unsurlarının belirlenmesi }\end{array}$ & 26 \\
\hline & 4 & Elektronik posta & 3 \\
\hline & 5 & Belge depolama & 4 \\
\hline & 6.1 & Belge gözden geçirme (screening) "Yaşam döngüsü" & 6 \\
\hline & 6.2 . & $\begin{array}{l}\text { Belge dosyalarının kapanması (closing) "Yaşam } \\
\text { Döngüsü" }\end{array}$ & 2 \\
\hline & 6.3. & $\begin{array}{l}\text { Belge dosyalarının işleminin sona ermesi (cutting off) } \\
\text { "Yaşam Döngüsü" }\end{array}$ & 2 \\
\hline
\end{tabular}




\begin{tabular}{|l|l|l|r|}
\hline 6.4. & $\begin{array}{l}\text { Belge dosyalarının dondurulması (freezing) ve tekrar } \\
\text { açılması (unfreezing) “Yaşam Döngüsü” }\end{array}$ & 4 \\
\hline 6.5. & Belge transferi “Yaşam Döngüsü” & 5 \\
\hline 6.6. & Belgelerin imhası “Yaşam Döngüsü” & 6 \\
\hline 6.7 & Hayatı belge döngüsü (Cycling Vital Records) & 4 \\
\hline 6.8 & Belge araştırma ve belge erişim & 9 \\
\hline 7 & Erişim kontrolü & 5 \\
\hline 8 & Sistem denetimi & 6 \\
\hline 9 & Sistem yönetimi & 6 \\
\hline
\end{tabular}

Tablo 3: DoD 5015.2 Olması Gerekli Unsurlar (DoD 5015.2, 2002; Gable, 2002, s.34)

DoD 5015.2 elektronik belgelerin yönetimi için gerekli unsurları tanımlamakla birlikte, her kurumsal yapının kendi gereksinimleri doğrultusunda bir belge akış ve buna bağlı belge sistemini oluşturması gerekmektedir. Kurumsal olarak üretilen ya da sağlanan dokümanların hangilerine ne aşamada belge statüsünün verileceğinin belirlenmesi, doğrudan o kuruma yönelik yapılacak analizlerin sonucunda belirlenebilmektedir.

Yukarda sıralanan tüm unsurlar, belge statüsü kazanmış dokümanlara yönelik, önceden belirlenmiş zaman aralıklarında yapılması gereken işlemleri ortaya koymaktadır. DoD 5015.2'nin 3. bölümde tanımlanan olmasında yarar görülen unsurlar ise şunlardır:

\section{DoD 5015.2 Zorunlu Olmayan Unsurlar Alt Bölüm Sayısı}

\begin{tabular}{|l|l|l|l|}
\hline \multirow{2}{*}{\begin{tabular}{l} 
Corunlu \\
\multirow{2}{*}{ Olmayan }
\end{tabular}} & 1. & Depolama olanakları & \\
\cline { 2 - 4 } & 2 & Dokümantasyon & \\
\cline { 2 - 4 } & 3 & Sistem performansı & \\
\hline
\end{tabular}




\begin{tabular}{|c|c|c|}
\hline \multirow[t]{6}{*}{ Unsurlar } & 4 & Donanım özellikleri \\
\hline & 5 & Sistem olanakları \\
\hline & 6 & Ağ olanakları \\
\hline & 7 & Protokoller \\
\hline & 8 & Elektronik posta ara yüzleri \\
\hline & 9 & Son kullanıcı oryantasyonu ve eğitimi \\
\hline \multirow{13}{*}{$\begin{array}{l}\text { C.3.2 } \\
\text { Diğer } \\
\text { Yararlı } \\
\text { Özellikler }\end{array}$} & 1 & Küresel değişimler \\
\hline & 2 & $\begin{array}{l}\text { Yığın (bulk) yükleme kapasitesi "Dosyalama ön } \\
\text { çalışmaları, elektronik belgeler ve üst veri } \\
\text { unsurları için" }\end{array}$ \\
\hline & 3 & Diğer yazılım uygulamaları için ara yüzler \\
\hline & 4 & Rapor yazma kapasitesi \\
\hline & 5 & Çevrimiçi yardım \\
\hline & 6 & Doküman görüntüleme araçları \\
\hline & 7 & Faks bütünleşme araçları \\
\hline & 8 & Bar kod sistemleri (elektronik olmayan belgeler için) \\
\hline & 9 & Erişim asistanı (örneğin tam metin taranması gibi) \\
\hline & 10 & Dosya planı unsurlarının seçimi/tarama kapasitesi \\
\hline & 11 & İş akışı ve veya doküman yönetim özellikleri \\
\hline & 12 & Belge yönetim formları ve diğer formlar \\
\hline & 13 & Yazılı etiketler (printed label) \\
\hline
\end{tabular}




\begin{tabular}{|l|l|l|l|}
\hline 14 & Görüntüleyici (viewer) & \\
\cline { 2 - 5 } 15 & Web kapasitesi & $\begin{array}{l}\text { Kamu bilgi yerleşim sitemi (government } \\
\text { information locator service) }\end{array}$ & \\
\cline { 2 - 5 } & 16 & Off-line belgeler için geliştirilmiş destek & \\
\cline { 2 - 5 } & 17 &
\end{tabular}

Tablo 4: DoD 5015.2 Olmasında Yarar Görülen Unsurlar (DoD 5015.2, 2002; Gable, 2002, s.34)

\subsection{ANSI/ARMA Standartları}

Amerikan Standartlar Enstitüsü (American National Standards Institute-ANSI) ile ARMA 1986 yılından itibaren belge ve arşivcilik alanında standartlar geliştirilmesi konusunda ortak çalışmalar yürütmeye başlamışlardır. ARMA çeşitli ülkelere yayılan 10.000 'in üzerinde üyesiyle belge yönetimi alanında küresel bir organizasyon konumundadır. ISO 15489'un oluşturulmasında aktif rol alan ARMA, 2000'li yılarla birlikte elektronik ortamdaki belge yönetimi ve belgelerin elektronik ortama aktarılmasına yönelik düzenleme ve standartlaşma çalışmalarına yoğunlaştırmıştır (ARMA International, 2007). Bu çerçevede bir dizi standart oluşturulmuş, kişi ve kuruluşların kullanımına sunulmuştur. Standartlar, gerek bir kurum için olsun, gerekse uluslararası ortak beklentileri ortaya koysun, bir ürün ya da hizmetin, boyutu ve beklentileri çerçevesinde olması gerekli asgari özelliklerini tanımlama amacını taşımaktadırlar. Bu kapsamda ISO 15489'un ardından ANSI (American National Standards Institute) ve ARMA'nın ortak çalışmaları sonucu ortaya çıkan standartlar oldukça önemli görülmektedir. ANSI/ARMA ortaklığıyla geliştirilen standartlar aşağıda başlıklar halinde tanımlanmaktadır:

> Belge Merkezi Operasyonları- ANSI/ARMA TR 02-2002

$>$ Hayati Belge Programları: Kritik İş Belgelerinin Tanımlanması, Yönetimi ve Yenilenmesi- ANSI/ARMA TR 5- 2003

> Elektronik Mesajların Belge Olarak Kabul GereklilikleriANSI/ARMA 9-2004

> Bilgi ve Belgeler için Saklama Yönetimi ANSI/ARMA 8-2005 
Alfabetik, Nümerik ve Konu Dosyalama Sistemlerinin Oluşturulması- ANSI/ARMA 12-2005 (ARMA International, 2007; Brumm, 2005, s.31).

Yukarıda yer alan standartlardan çalışma konusuyla ilişkili görülen ikisi aşağıda kısaca tanıtılmaktadır.

\subsubsection{ANSI/ARMA 8-2005: Belge ve Bilgi İçin Saklama Yönetimi (Retention Management for Records and Information)}

ANSI/ARMA tarafından hazırlanan standart, örnek bir belge saklama modeli de sunmaktadır. Standart üretilen ve kullanılan belgelere yönelik, saklama programlarının geliştirilmesi için kullanılabilecek bilgiler içermektedir. Standart içerisinde belge yönetimi politikalarının oluşturulması, belge yönetim ve belge saklama programlarının içerikleri, sorumluluklar ve program sonucu elde edilebilecek sonuçlara ilişkin bilgiler yer almaktadır. Bu kapsamda belge saklama şemaları, belge merkezlerine dosya transferi ve ayıklamaya ilişkin diğer unsurlar, Standart içerisinde yer almaktadır. Standartta "Belge Saklama Şemaları Geliştirme İşlemi" adım adım tanımlanmıştır (American National Standards Institute, 2005; Brumm, 2005, s.34).

2.5.2. ANSI/ARMA 9- 2004: Elektronik Mesajların Belge Olarak Gereklilikleri (Requirements for Electronic Messages as Records)

Standart diğer ANSI/ARMA standartlarından ve ISO 15489'dan farklı olarak elektronik ortamda üretilen ve mesaj içeriğine sahip dokümanların yönetimi için ortak politikalar geliştirmeyi amaçlamaktadır. Bu çerçevede Standart:

Elektronik belgelerin işlevleri,

$>$ Güvenlik ve özgünlük ölçütleri,

$>$ Ek dosyaları da kapsayan içerik yönetimi (content management)

Elektronik mesaj politikalarının oluşturulmasına yardımcı olacak örnek dokümanları kapsamaktadır (ARMA International, 2004; Brumm, 2005, s.34). 
Anlatılar çerçevesinde genel olarak ANSI/ARMA ve ISO 15489 Standartları içerisinde belge yönetimi programları geliştirilmesinde aşağıdaki akışın izlenmesi öngörülmektedir.

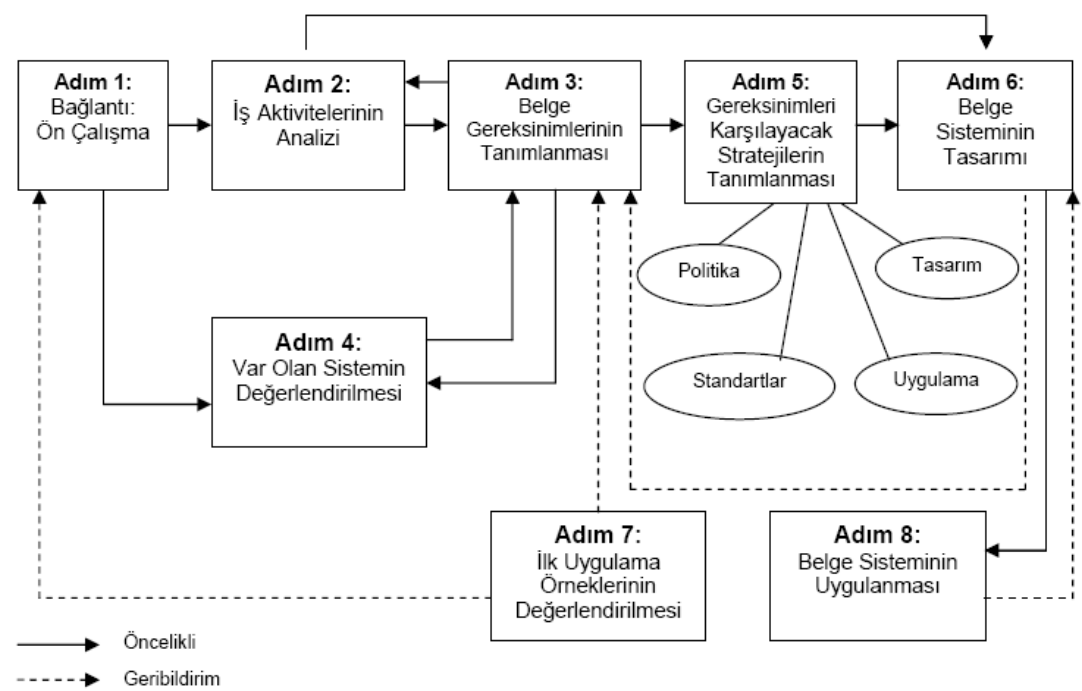

Şekil 1: Belge Yönetim Sistemlerinin Tasarımı ve Uygulanması (Brumm, 2005, s.32)

ANSI/ARMA Standartları belge yönetim programları için anahtar unsurları tanımlamakta, programlar için daha ayrıntılı uygulamaların çerçevesini çizmektedirler (Brumm, 2005, s.32). Ancak gerek ANSI/ARMA standartları, gerekse ISO 15489 çerçevesinde bir belge yönetimi programı uygulamaya geçilmeden; kurumsal amaçların, bu çerçevede var olan belge ve arşiv sisteminin tanımlanması ve standartların uygulanışıyla geliştirilmesi düşünülen alanların ortaya konulması gerekli görülmektedir. Bu kapsamda aşağıdaki unsurlar çerçevesinde "Gap Analizinin" (mevcut durum ve hedeflenen durumun karşılaştırılmasına dayalı bir analiz yöntemi) öncelikle yapılması gerektiği üzerinde durulmaktadır. 


\begin{tabular}{|l|l|}
\hline Belge Teknolojileri & Hangi teknolojiler kullanılacak? \\
\hline Risk Yönetimi & Belge yoksa hangi riskler ortaya çıkabilir? \\
\hline Denetim & Düzenli olarak yürütülüyor mu? \\
\hline Enformasyon Kullanımı & Kullanıcıların gereksinimleri nelerdir? \\
\hline $\begin{array}{l}\text { Güncel Olmayan } \\
\text { Belgeler }\end{array}$ & $\begin{array}{l}\text { Maliyeti düşük alanlarda mı depolanıyor? Hizmet } \\
\text { düzeyi geliştirlebilir mi? }\end{array}$ \\
\hline Saklama Şeması & $\begin{array}{l}\text { Belgeler gereksinimler doğrultusunda elde } \\
\text { bulundurulup sonrasında inha ediliyor mu? }\end{array}$ \\
\hline E-Belgeler & $\begin{array}{l}\text { Belge yönetim programı elektronik belgeler için } \\
\text { de uygulanabiliyor mu? }\end{array}$ \\
\hline Erişebilirlik & $\begin{array}{l}\text { Belgeler nasıl organize ediliyor? Belgelerin } \\
\text { sağlanması, kullanımı ve iletiminde gereksinimler } \\
\text { nelerdir? }\end{array}$ \\
\hline Üretilen Belgeler & Belgelerde hangi bilgiler yer alıyor? \\
\hline Eğitim & $\begin{array}{l}\text { Yeni alınan çalışanlar belge yönetim } \\
\text { programı konusunda eğitime alınıyor mu? }\end{array}$ \\
\hline Önemli Belgeler & $\begin{array}{l}\text { Belgeler güvenli ve uygun alanlarda } \\
\text { korunuyor mu? }\end{array}$ \\
\hline Yasal Düzenlemeler & $\begin{array}{l}\text { Belge saklama şeması kurumsal } \\
\text { gereksinimler ve yasal koşullarla uyumlu } \\
\text { mu? }\end{array}$ \\
\hline
\end{tabular}

Tablo 5. ANSI/ARMA ve ISO 15489 Standartları Çerçevesinde Gap Analizi (Brumm, 2005, s.32)

Gap analizinin gerçekleştirilmesinin ardından; genel anlamda belge yönetimi politikaların geliştirilmesi, bu kapsamda gerekli işlemlerin (prosedürlerin) tanımlanması, sistemin işleyişi uygulama 
biçimlerinin ortaya konulması sistemin sürekliliğin ve işleyişinin denetlenmesi gerekli görülmektedir (Brumm, 2005, s.32).

\subsection{Kalıcı Belgelerin Korunmasına Yönelik Standartlar}

Kalıcı değere sahip belgeleri korumaya yönelik pek çok ulusal standart bulunmaktadır. Ancak bu standartlar içerisinde özellikle NFPA, uluslararası kullanım değerine sahip olmuştur. NFPA standartları aşağıdaki üç başlıktan oluşmaktadır:

> NFPA 75: Elektronik Bilgisayar/Veri İşleme Ekipmanları Koruma Standardı, 1999

> NFPA 232: Belge Koruma İçin Standart, 2000

> NFPA 909: Kültürel Kaynakların Korunması İçin Kanun, 2001

ISO 15489 kurumsal belgelerin yaşam döngüsünün tüm evrelerinde etkin yönetimi için geliştirilmiş bir standartken, NFPA 75 elektronik ortamda bilgisayar ve veri işlem ekipmanlarına ait bilgi kaynakları ile bilgisayar alanlarının hemen dışında bulunan belge depolama alanlarında kaynakların korunmasına yönelik ilkeleri ortaya koymaktadır (Jones, 2003:70). NFPA 232 ise tüm formatlarda bilgi ve belge kaynaklarının özellikle yangına karşı korunmasını sağlamaya yönelik ilkeleri belirlemektedir. Bu ilkeler belge koruma için gerekli araç gereçleri de tanımlamaktadır. Üçüncü standardı oluşturan NFPA 909 kültürel kaynakları ve bu kaynakları içeren müze, arşiv ve kütüphaneler gibi kurumlara yönelik yapısal koşulları ortaya koymaktadır (Jones, 2003, s.71).

ABD'de özellikle kamu kesiminde yangın elektrik ve yaşam güvenliği konularında çözümler üretmek amacıyla 1896 yılında Ulusal Yangın Önleme Derneği (National Fire Protection Association-NFPA) kurulmuştur. Günümüzde uluslararası bir niteliğe sahip olan kuruluş, yaşam kalitesini artırma, yangın ve diğer felaketlere karşı önemler geliştirme üzerine çalışan kâr gözetmeyen bir oluşumdur. NFPA, dünya üzerine ticari ya da profesyonel organizasyonların yer aldığı 80 ayrı ülkede 75.000 üyeye sahiptir. NFPA içerisinde yer alan ülke ya da kuruluşlar, belgesel değere sahip materyallerin korunmasına yönelik standartlar, yönetmelikler geliştirmeye, ilgili konuda araştırmalar yapmaya ve bu konularda eğitim ve öğretim çalışmalarını 
yürütmeye çalışmaktadırlar (National Fire Protection Association, 2006).

2.6.1. NFPA 75: Bilgi Teknolojisi Ekipmanları Koruma Standardı (Standard for Information Technology Equipment Protection)

NFPA 75 risk yönetimi, yapısal gereksinimler, bilgisayar araç gereç gereksinimleri, yangın önleme ve tespit araçları, acil durum ve iyileştirme işlemlerinin ortaya koymaktadır. Ayrıca bilgisayar ortamlarında bulunan belge ve arşiv kaynaklarının korunmasına yönelik araçlar ve koruma yöntemlerini belirlemektedir.

Standardın 4. bölümü bilgisayar ortamlarında bulunmasına izin verilen materyaller ve araç gereçlere, 7 . bölümü bilgisayar odalarında korunan ve depolanan belgelere, 7.1. bölümü bilgisayarların yer aldığı ortamlarda belgelerin korunması için öngörülen önlemlere, 7.2. bölümü bu ortamlarında dışında depolanan belgelere ayrılmıştır (Jones, 2003, s.73; NFPA 75, 2006).

\subsubsection{NFPA 232: Belge Koruma İçin Standart (Standard for the Protection of Records)}

NFPA 232 Yangın tehlikesine karşı belgeleri korumak için bulundurulması gerekli koruma araç gereçleri ve olanakları ile bu ortamlarda belgelere yönelik gerçekleştirilmesi öngörülen işlemlere yönelik bilgiler içermektedir. Standart genel olarak belgelere yönelik dört ayrı kategoride bir koruma planı ortaya koymaktadır.

1. Önemli Belge Depoları (records vaults): En yüksek koruma gerektiren alanları oluşturmaktadır

2. Dosya Odaları: Güncel ve yarı güncel belgelere yönelik orta düzey koruma alanlarından oluşmaktadır.

3. Arşiv Depoları: Kalıcı değere sahip belgelere yönelik yüksek düzey koruma alanlarını oluşturmaktadır.

4. Belge Merkezleri: Geçici değere sahip belgelere yönelik orta düzey koruma alanlarını oluşturmaktadır (Jones, 2003, s.74; NFPA 232, 2006) 
2.6.3. NFPA 909: Kültürel Kaynakların Korunması İçin Düzenleme (Code for the Protection of Cultural Resources Properties)

NFPA 909 kültür varlığı kapsamına giren her türlü malzeme ile bina ve aracı içine alan geniş bir alanda tanımlanmaktadır. NFPA 909'un 1.5.12. maddesi, koleksiyonlar başlığı altında arşiv kaynaklarını, kütüphane araçlarını ve kültürel malzemelerini içermektedir. Bu kaynakların korunması, araştırmaya açılması, ilgili kaynaklara yönelik sergiler açılması, yayınlar yapılması gibi, kamusal amaçlarla malzeme ya da ortamların kullanımına yönelik çalışmalar, ilgili düzenleme içerisinde yer almaktadır. Kültür mirasına giren arşiv ve müze kaynaklarının korunması Kanunun 8.9. maddesi içerisinde ele alınmaktadır (Jones, 2003, s.75; NFPA 909, 2006).

\section{Küresel Gelişmelerin Türkiye'ye Yansımaları}

Çalışma içerisinde ayrıntılarına değinildiği gibi özellikle 90'lı yıllarla birlikte ivme kazanan "küreselleşme" olgusu etkilerini ülkemizde son yıllarda artarak hissettirmektedir. Cumhuriyetin ilk yıllarından günümüze ülkemizde devlet politikaları bir yandan ulusal kimliğin yaşatıması, diğer yandan uluslararası ilişkilerden doğan sorumlulukların kararlılıkla yerine getirmesi üzerine odaklanmıştır (T.C. Başbakanlık Devlet Planlama Teşkilatı Müsteşarlığı, 2007). Birleşmiş Milletlerin kurucu üyesi olan (Charter of the United Nations, 1945) Türkiye, İktisadi İşbirliği ve Gelişme Teşkilatı (Organization for Economic Co-operation and DevelopmentOECD, 2007)'nin de tam üyesidir.

Avrupa kıtası içerisinde kurumsal ve bölgesel düzeyde pek çok olanda ortak çalışmalar yürüten, Dünya Bankası (Kaya, 2002) ve Dünya Ticaret Örgütü (World Trade Organization; T.C. Başbakanlık Dış Ticaret Müsteşarlığı, 2007) gibi kurumlarda çeşitli düzeylerde temsil edilen Türkiye, dünya üzerinde belli başlı küresel güçlerden birini oluşturmaktadır. AB, Birleşmiş Milletler, UNESCO $\mathrm{vb}$. küresel oluşumların içerisinde daha aktif olarak yer almaya yönelik çabalar ile uluslararası ölçüt, standart ya da uygulamaların yaygınlaştırılmasına dönük çabalar, bu sürecin hızlanmasını tetikleyen unsurlar arasındadır. Günümüzde geliştirilen uluslararası ölçütlerin uygulamaya yansıması son derece hızlı 
gerçekleşebilmektedir. Uluslararası Standartlar Örgütü ISO'nun (International Organization for Standardization) kabul ettiği bir standardın, aynı içerikle belirli bir süre sonra Türk Standartlar Örgütü (TSE) tarafından da kabul edildiğini ve bu sürecin aşağı yukarı tüm ülkelerde aynı olduğunu görüyoruz. Örneğin ISO tarafından tüm kurumlarda belirli kalite ölçütlerinin belirlenmesine yönelik hazırlanan bir standart Avrupa Birliği EN ISO, Almanya DIN ISO, İngiltere BSI EN ISO Türkiye TS EN ISO kodlarıyla (Bozkurt 1999, s.13; European Committee for Standardization , 2004; TS EN ISO 9000 2001) yayımlayabilmektedir. Bu örnekleri pek çok alanda çoğaltmak mümkündür. Uluslararası ilişkilerin tetiklediği bu sürecin önemli bir etkisinin de belge yönetimi ve arşivcilik çalışmalarına olduğu bilinmektedir. Ülkemizde 2004'de kabul edilen Elektronik İmza Kanunu'nun. (Elektronik Imza Kanunu, 2004), çalışma içerisinde değinilen Birleşmiş Milletler tarafından çıkarılan aynı içerikli kanundan bağımsız olarak ele alınması mümkün görünmemektedir. Benzer biçimde Bilgi Edinme Hakkı Kanununu (Bilgi Edinme Hakkı Kanunu, 2003) bilgiye serbest erişimi hedefleyen uluslararası düzenlemelerden "Freedom of Information Ac" (Waldron, 2004, s.31) ayrı değerlendirilmemesi gerekmektedir.

\subsection{Gelişen Koşulların Türkiye'de Belge ve Arşiv Uygulamalarına Yansımaları}

Ülkemizde belge ve arşiv uygulamalarında gözlenen değişime değinmeden önce bir durum saptaması yapmak yararlı görülmektedir. 1984 tarihinde yürürlüğe giren "Başbakanlık Teşkilatı Hakkında Kanun Hükmünde Kararnamenin Değiştirilerek Kabulü Hakkında Kanun"un kabul edilmesiyle (Başbakanlık Teşkilatı Hakkında Kanun Hükmünde Kararnamenin Değiştirilerek Kabulü Hakkında Kanunun, 1984) ülkemizde belge ve arşiv çalışmalarına yönelik tüm düzenlemeler, Başbakanlık çatısı altına alınmış ve Devlet Arşivleri Genel Müdürlüğü (DAGM) kurulmuştur. Başbakanlık Teşkilat Kanununda yapılan değişikliğin ve Devlet arşiv hizmetlerinin esaslarının belirlenmesinin ardından, kamu kuruluşlarının elinde bulunan belge ve arşiv kaynaklarına yönelik bir düzenlemenin yapılması gereksinimi duyulmuş ve 28 Eylül 1988 tarihinde "3473 sayılı kanun" yürürlüğe girmiştir. 
$\mathrm{Bu}$ konuda daha önce gerçekleştirilen düzenlemelerin geliştirilmesiyle ortaya çıkan Kanun ile arşiv malzemesi, arşivlik malzeme, ayıklama ve imha çalışmaları tanımlanmış, kanun kapsamında yer alan kurum ve kuruluşlara getirilen yaptırımlar sıralanmış; ayıklama ve imha işlemlerinin, kurum ve kuruluşlarca kurulacak komisyonlar yoluyla gerçekleştirilmesi hükme bağlanmıştır (Muhafazasına Lüzum Kalmayan Evrak ve Malzemenin Yok Edilmesi Hakkında Kanun, 1988). 3473 sayılı Kanunun 6. maddesi gereğince, kamu kurumları ile şahısların elinde bulunan arşiv malzemesi ve ileride arşiv malzemesi olacak arşivlik malzemenin tespit edilmesine, korunmasına, ilgili kişilerin kullanımına sunulmasına, muhafazasına lüzum görülmeyen malzemenin ayıklama ve imhası ile kurumlar içerisinde ayıklama ve imha işlemlerini yürütecek komisyonların çalışmaları ve kuruluşların yüklenecekleri sorumluluklara yönelik, "Devlet Arşiv Hizmetleri Hakkında Yönetmelik" Başbakanlıkça hazırlanarak 16 Mayıs 1988 tarihinde Resmî Gazete'de yayımlanarak yürürlüğe girmiştir (Devlet Arşiv Hizmetleri Hakkında Yönetmelik, 1988). Yönetmelik, kamu kurumlarında belge işlemlerini belirleyen genel kapsamlı tek ve en önemli düzenleme olma özelliğini korumaktadır.

Ancak değişen koşullarda çağın gereksinimlerine uygun olarak, ülkemizde belge ve arşiv çalışmalarını doğrudan etkileyen çeşitli düzenlemeler gerçekleştirilmiştir. $\mathrm{Bu}$ düzenlemeler aşağıda başlıklar halinde verilmektedir.

1. "Ayıklama ve İmha İşlemlerinde DAGM'nün Uygun Görüşünün Alınması, Yıllık Arşiv Faaliyet Raporunun Aksatılmadan Gönderilmesi, Yönetim Kurulu ve Benzeri Kararlar İle Eski Harfli Türkçe Arşiv Malzemesinin Bekletilmeden Devlet Arşivlerine Devri”. Başbakanlık Genelgesi, Sayı: 18975, 20 Ekim 1998

2. Devlet Arşiv Hizmetleri Hakkında Yönetmelikte Değişiklik Yapılmasına Dair Yönetmelik. (2001). Resmî Gazete, Sayı: 24487, 08 Ağustos 2001

3. Bilgi Edinme Hakkı Kanunu. (2003). Resmî Gazete, Sayı: 25269, 24 Ekim 2003 
4. Elektronik İmza Kanunu. (2004). Resmî Gazete, Sayı: 25355, 23 Ocak 2004

5. Bilgi Edinme Hakkı Kanununun Uygulanmasına İlişkin Esas Ve Usuller Hakkında Yönetmelik. (2004). Resmî Gazete, Sayı: 25445, 27 Nisan 2004

6. Resmi Yazışmalarda Uygulanacak Esas ve Usuller Hakkında Yönetmelik. Resmî Gazete, Sayı: 25658, 02 Aralık 2004

7. "Standart Dosya Planı İle İlgili Başbakanlık Genelgesi". T.C. Başbakanlık Personel ve Prensipler Genel Müdürlüğü”, Sayı: 320-3802, 24 Mart 2005: 1-55

Bu düzenlemelerle birlikte DAGM'nin Kuruluş ve Görevleri ile "Milli Hakkında Kanun Tasarısı" (Milli Arşiv Kanun Tasarısı, 2007, ss.1-11) ve "Ulusal Bilgi Güvenliği Teşkilatı ve Görevleri Hakkındaki Kanun Tasarısı" hazırlanmış (Elektronik Belge Yönetimi Sistem Kriterleri Referans Modeli, 2005, s.88) ve 4 Mayıs 2006 tarihinde TBMM'de Milli Eğitim Komisyonu'ndan geçerek yasallaşma süreci hız kazanmıştır.

Ülkemizde belge ve arşiv uygulamalarının uluslararası koşullar çerçevesinde yeniden düzenlenmesine örnek bir çalışma olarak, Türk Standartlar Enstitüsü'ne bağlı Bilgi Teknolojileri ve İletişim İhtisas Grubu tarafından ISO 15489 Uluslararası Belge Yönetimi Standardı ve teknik raporu Türkçeye çevrilmiş ve Temmuz 2007'de standart olarak kabul edilmiştir. Standardın amacı, özel sektör ve kamu sektöründeki iç ve dış kullanıcılar tarafından üretilen belgelerin yönetilmesine rehberlik edecek bilgileri sağlamak olarak özetlenmektedir (Türk Standartları Enstitüsü, 2007a). Belge ve arşiv programlarını geliştirme açısından problem yaşayan kurumlara yol gösterici nitelikteki standardın, yeni istihdam olanaklarının da yaratılabileceği düşünülmektedir.

Ülkemizde özellikle 2000'li yıllarla birlikte, belge ve arşiv uygulamalarının geliştirilmesi ve ilgili alanda uluslararası standartları ele alan bir dizi kuramsal çalışma yapılmıştır. Bu çalışmaların alanın kuramsal altyapına sağladığı katkı yanında, gelecekte uygulama modeli, standart ve yasal düzenlemelerin 
geliştirilmesine zemin oluşturacağı ve hatta oluşturmakta olduğu düşünülmektedir. Bu çerçevede 2000 tarihinde Arşiv Araştırmaları Dergisi'nde ISO 9000 kalite standardı ile belge yönetimi arasındaki ilişkiyi ele alan bir çalışma yayımlanmıştır (Çiçek, 2000, ss.7-34). 2003 tarihinde Türk Kütüphaneciliği Dergisi'nde yayımlanan bir başka çalışmada (Özdemirci, 2004, ss.225-246) ise, uluslararası belge yönetimi standardı ISO 15489 çok yönlü olarak değerlendirilmiştir.

Bu kapsamda belge yönetimi alanında ilk uluslararası standart olan ISO 15489'un "hazırlık çalışmaları, içeriği ve belge yönetimine kazandırdığı yeni boyutlar" irdelenmiş, ISO 15489'un belge ve arşiv yönetimi ile ilişkisi açıklanmıştır. Standardın ülkemizde belge ve arşiv yönetimi uygulamalarına sağlayacağı katkılar üzerinde durulan çalışmada, ülkemizde ilgili konuda yapılması gerekenler ve Türk Standartları Enstitüsünün rolü üzerine yaklaşımlar önemli görülmektedir. Nitekim çalışmanın yayımlanmasından birkaç yıl sonrasında Türk Standartlar Enstitüsünün ilgili konuda standart hazırlama faaliyetlerine başladığına tanık oluyoruz. Belge yönetiminde standartlaşma ve uluslararası uygulamaları ele alan bir diğer çalışmada, Avrupa Birliği çerçevesinde gerçekleştirilen proje, standart ve uygulamalar değerlendirilmiştir (Külcü, 2006, ss. 202-229).

Çalışma içerisinde değinilen, belge işlemlerini etkileyen ya da bu işlemleri belirleyen uluslararası düzenleme, standart, uygulama örneklerine benzer düzenlemelerin ülkemizde yakın geçmişte yasallaştığı ya da yayımlandığı memnuniyetle görülmektedir. Bu çalışmalara örnekler aşağıda verilmektedir.

\subsection{Standart Dosya Planı}

Dosyalama sistemlerinde standartlaşma, belge yönetimi alanında üzerinde önemle durulan konular arasındadır. Gerek basılı gerekse elektronik ortamda üretilen belgeleri tanımlamasında, bu belgelerden oluşan seri ve fonların yerleşimi ve erişiminde, ortak kodlama sistemlerinin kullanılması kurumsal iletişim kadar, ortak kültürel mirasın korunması ve erişilebilirliği açısından da önem taşımaktadır. Bu çerçevede "kurum ve kuruluşlarca müşterek kullanılacak standart dosya planı hazırlamada uyulacak esaslara" 
yönelik Başbakanlık ve Devlet Arşivleri Genel Müdürlüğü'nce "Standart Dosya Planı" geliştirilmiştir.

Kurum ve Kuruluşlarca Müşterek Kullanılacak Standart Dosya Planı Hazırlamada Uyulacak Esaslar adlı Genelge, kamu kurumlarında belgelerin düzenlenmesinde tekdüzeliği, kapsamlıı̆̆ı ve eşgüdümü sağlama amacını gütmektedir. Çalışmalar, Başbakanlıkça başlatılan "e-Türkiye" projesi kapsamında oluşturulan "Arşiv ve Dijital Depolama Çalışma Grubu" tarafından yürütülmüştür. Genelgede, elektronik ortamlarda belgelerin üretilmesi ve dosyalanmasında gereken altyapı oluşturularak, gerek fiziki, gerekse elektronik ortamlarda belgelerin aynı esaslar dâhilinde dosyalanmasına imkân sağlamak amacıyla, kamu kurum ve kuruluşlarının tamamında, "Standart Dosya Planları" uygulanması esas alındığından söz edilmektedir. Böylece her kurumda belge serilerinin başlıklarının belirlenmesinde ve kodlamalarda standartlaşma sağlamak, ilgili belgelerin hızlı ve kolay bir şekilde düzenlenmesi, depolanması ve saklanması için elektronik ortamların gelişmesine olanak yaratmak amaçlanmıştır. Ayrıca kurum ve kuruluşlar arasında etkili, düzenli, hızıı ve verimli bir haberleşme ve bilgi sisteminin kurulmasına zemin oluşturmak hedefler arasında sıralanmıştır (Standart Dosya Planı, 2002, ss.1-2).

\subsection{Bilgi Edinme Hakkı Kanunu}

Çalışma içerisinde değinilen bilgiye serbest erişimi hedefleyen düzenlemelere benzer bir uygulama ülkemizde "Bilgi Edinme Hakkı Kanunu" olarak 2003 yılında yasallaşmıştır. Bilgi Edinme Hakkı Kanununun amacı; "demokratik ve şeffaf yönetimin gereği olan eşitlik, tarafsızlık ve açıklık ilkeleri çerçevesinde, bilgi edinme hakkına ilişkin esas ve usulleri düzenlemek" olarak belirlenmiştir. Kanunda 10.11.1984 tarih ve 18571 sayı ile Resmî Gazete de yayımlanan Dilekçe Hakkının Kullanıımasına Dair Kanun hükümleri saklı tutulmuştur (Bilgi Edinme Hakkı Kanunu, 2003).

Kanunun 3. maddesinin d fıkrasında; "kurum ve kuruluşların sahip oldukları yazılı, basılı veya çoğaltılmıs dosya, evrak, dergi, broşür, etüt, mektup, program, talimat, kroki, plan, film, fotoğraf, teyp ve video kaset, harita, elektronik kaydedilen her türlü bilgi, haber ve veri taşıyıcısı" belge olarak tanımlanmaktadır (Bilgi Edinme Hakkı Kanunu, 2003, s.1). Aynı madenin e. fıkrasında 
belgelere erişim ilkeleri belirlenmiştir (Bilgi Edinme Hakkı Kanunu, 2003, s.1). Kanunun 3. bölümü bilgi edinme başvurusuna yönelik izlenecek yolu tanımlamaktadır. 11. maddede bilgi ve belgeye erişim süresi başvuru tarihinden itibaren en geç 15 gün olarak belirlenmiştir. Bilgi ve belgenin sağlanması için başka bir kurumun görüşünün alınması gerektiği ya da başvurunun birden çok kurumu ilgilendirmesi durumunda, bu süre 30 güne kadar uzatılabilmektedir (Bilgi Edinme Hakkı Kanunu, 2003, s. 2). Kanunun 14. maddesi "Bilgi Edinme Değerlendirme Kurulunun" kimlerden oluştuğunu tanımlamaktadır. (Bilgi Edinme Hakkı Kanunu, 2003, s.4). Kanunun 4. bölümü, başvurulan bilgi ve belgenin sağlanmasına yönelik kısıtlamaları ve erişim koşullarını tanımlamaktadır. Genel olarak ilgili bölüm; yargı denetimi dışında kalan işlemlerle; devlet sırrına, ülkenin ekonomik çıkarlarına, istihbarata, idari soruşturmaya, adli soruşturma ve kovuşturmaya, özel hayatın gizliliğine, haberleşme gizliliğine, ticari sırlara, fikir ve sanat eserlerine, kurum içi düzenlemelere, kurum içi görüş, bilgi notu ve tavsiyelere, tavsiye ve mütalaayla, gizliliği kaldırılan bilgi ve belgelere yönelik erişim sınırlamaları ve koşullarına ilişkin hükümler içermektedir (Bilgi Edinme Hakkı Kanunu, 2003, s.5). Kanunu 5. bölümünde, ceza hükümleri yanı sıra, kurumların yıllık olarak bir önceki yıla ait, bilgi edinme hakkının kullanımına ilişkin rapor yayımlaması zorunlu tutulmuştur (Bilgi Edinme Hakkı Kanunu, 2003, s.8). Bilgi Edinme Hakkı Kanunu içeriği itibariyle kurumda belge işlemlerini yürüten birimleri doğrudan ilgilendirmektedir. Kanunda belirlenen hükümlerin doğru uygulanması ve gerekli zaman dilimlerine riayet edilebilmesi için, belge yönetimi ve alıkoyma programları kapsamında gerekli çalışma birimleri oluşturulmalıdır. Bilgi Edinme Hakkı Kanunu içeriği itibariyle kurumda belge işlemlerini yürüten birimleri doğrudan ilgilendirmektedir. Kanunda belirlenen hükümlerin doğru uygulanması ve gerekli zaman dilimlerine riayet edilebilmesi için, belge yönetimi ve saklama programları kapsamında gerekli çalışma birimleri oluşturulma gerekmektedir (Külcü, 2005, s.142) .

\subsection{Elektronik İmza Kanunu}


Elektronik belgelerin giderek basılı belgelerin yerini alması karşısında, elektronik ortamda belgelerin özgünlüğünü ve güvenilirliğini ortaya koymaya dönük düzenlemeler çalışma içerisinde değerlendirilmiştir. Bu çerçevede yakın tarihte ülkemizde de benzer içerikte bir düzenleme yürürlüğe girmiştir.

2004 yılında yürürlüğe giren Elektronik İmza Kanununun amacı, "elektronik imzanın hukuki ve teknik yönleri ile kullanımına ilişkin esasları düzenlemek" olarak belirlenmiştir. Kanun elektronik imzanın hukuki yapısını, elektronik sertifika sağlayıcılarının faaliyetlerini ve farklı ortamlarda elektronik imzanın kullanımına ilişkin işlemleri kapsamaktadır. Elektronik İmza Kanunu, elektronik belgelere yasal içerik kazandırma amacını gütmektedir (Elektronik İmza Kanunu, 2004). Kanunun içeriği ve kapsamı itibariyle sadece kurumsal yönetim ve elektronik uygulamalar alanındakiler tarafından değil, belge yönetiminden sorumlu birimlerce de titizlikle incelenmesi ve kurumsal uygulamalarla ilgili gerekli koşulların sağlanması gerekmektedir. Belge işlemlerini yürüten birimler sertifika sağlayıcı kuruluşlar ile elektronik belgeleri sağlayan ya da üreten birimler arasında köprü görevi üstlenebilecekleri düşünülmektedir.

\subsection{Elektronik Belge Yönetimi Sistem Kriterleri Referans Modeli (EBYSKRF)}

Elektronik Belge Yönetimi Sistem Kriterleri Referans Modeli (EBYSKRF), Marmara Üniversitesi ve DAGM'nün birlikte yürüttüğü bir proje kapsamında Hamza Kandur tarafından 2005 yılında hazırlanmış ve gözden geçirilmiş ikinci baskısı 2006 tarihinde basılmıştır (Elektronik Belge Yönetimi Sistem Kriterleri Referans Modeli, 2006).

EBYSKRM'nin amacı, "kamu kurumlarında üretilen ve/veya üretilmesi muhtemel elektronik belgelerin arşiv belgesi niteliğinin korunabilmesi için gerekli standartların belirlenmesi" olarak saptanmıştır.

Elektronik belge yönetimi sistemlerinin tasarlanması, çevresel unsurlarla birlikte tanımlanması, bu sistemlerle uyumlu yazılım ve donanım olanaklarının belirlenmesi, elektronik bilgi ve belge sistemleri için ölçütlerin saptanması, belge yönetimi çalışmalarına 
yönelik politika ve izleklerin oluşturulmasında hazırlanan modelin önemli etkiler yaratabileceği düşünülmektedir. Model içerisinde sistem ölçütleri yedi bölümde ele alınmaktadır. Bu kapsamda belge özellikleri, belge yönetimi, elektronik olmayan sistemlerle uyumluluk ve sayısal görüntüleme sistemleri başlıkları altında gerekli ölçütler ve bilgiler sunulmaktadır. EBYSKRM, içerisinde ayrıca üst veri elemanlarına yönelik ölçütler tanımlanmaktadır. Türk Standartları Enstitüsü EBYSKRM'ni 19 Haziran 2007 tarihinde TSE 13298 koduyla "Bilgi ve dokümantasyon - Elektronik belge yönetimi" adlı standart olarak kabul etmiştir.

\section{Değerlendirme ve Sonuç}

Özellikle 90'lı yıllarla birlikte hızlanan değişim süreci kurumları giderek küreselleşen koşullarda bütünleşik programlara yönelmemiş ve çok uluslu ortak çalışma alanlarının yaygınlaşmıştır. Yine teknolojik gelişmelere paralel yoğun ve karmaşık bilgi iletişimi, standartlaşma gereksinimi artırmıştır. Belge yönetimi alanında geliştirilen pek çok düzenleme, standart ve uygulama örneği, uluslararası güç birliğinin yarattığı sinerjinin sonucu gerçekleşmiştir. Bu durum bir yandan hizmet kalitesinin artışını ve standartlaşmayı sağlarken, hizmet politikalarının oluşturulmasında güçlük çeken kurumlar için de yol gösterici olmuştur. Belge yönetiminde uluslararası uygulamaların ve geliştirilen standartların sağladığı önemli bir katkı da alanın tanınması ve kurumlar için temel idari yönetim unsurlarından biri olarak benimsenmesidir. Böylece ISO kalite belgesi almak isteyen kurumlar, belge yönetimi alanında ISO tarafından belirlenen gereklilikleri de yerine getirmek durumunda kalmaktadırlar. Yine ISO tarafından başlı başına kurumlarda belge yönetimi uygulamalarına dönük geliştirilen ISO 15489 standardı ile belge yönetimi çalışmalarının çok daha geniş bir alanda uygulanmaya başlanmıştır. Ülkemizde ISO 9000 ve daha sonra ISO 9001'in TSE standardı olarak yayımlanmasıyla, kalite belgesi almak isteyen kurumlar belge yönetimi uygulamalarını gerçekleştirmek durumunda kalmışlardır. 2007 yılı içerisinde uluslararası belge yönetimi standardı ISO 15489 bir Türk standardı olarak kabul edilmesinin ise, ülkemizde belge yönetimi alanında profesyonel çalışmalara ivme kazandıracağı düşünülmektedir. 
Çalışmalarını uluslararası arenada yürüten mesleki dernekler de alanın gelişiminde etkin rol almışlardır. Çalışma içerisinde değinilen mesleki dernekler ya kuruluş aşamasında çokuluslu niteliğe sahip olmuş ya da çalışma alanlarını zamanla uluslararası boyuta taşımış ve bu çerçevede pek çok gelişmeye öncülük etmişlerdir. Ülkemizde başta ulusal arşivimiz olmak üzere ilgili kişi ve kurumların uluslararası dernekler ve oluşumlarla daha yakın ilişkiler geliştirmesi beklenmektedir.

Kurumlarda belge işlemleri kurumun yasalarla belirlenmiş iş akışı doğrultusunda gerçekleştirilmektedir. Yasal koşullardaki değişim doğal olarak belge işlemlerini de etkilemekte ve bu alanda programların yeniden tanımlanmasını gerekli kılmaktadır. Bu çerçevede çalışma içerisinde de ele alındığı gibi, uygulamaları ortaya koyan yasal koşulların ulusal sınırların ötesinde uluslararası boyutta tanımlanmaya başlanması, ilgili alanlarda belge işlemlerini de etkilemektedir. Uluslararası ilişkilerde yaşanan gelişmeler ve İnternet ortamında ticaretin yaygınlaşmasının da etkisiyle Birleşmiş Milletler, Avrupa Birliği, ya da çeşitli alanlarda faaliyetlerini yürüten oluşumlar, belge işlemlerini de doğrudan etkileyen çeşitli düzenlemeler geliştirmiştir. Çalışma içerisinde değinilen yasal düzenlemelerin belge yönetimi alanındaki değişimlere önemli etkileri olmuştur.

Ülkemizde özellikle 2000'li yıllarla birlikte uluslararası koşulların da etkisiyle idari ve yasal düzenlemelerde köklü değişiklikler yapılmıştır. Bu düzenlemeler, idari koşulları ve kurumsal işleyişi pek çok yönüyle yeniden tanımlamış, uzantısı olarak belge işlemlerinin de etkilemiştir. Örneğin Bilgi Edinme Hakkı Kanunu bu sürecin dışında değerlendirmek olası görünmemektedir.

Diğer yandan elektronik belge yönetimi, uygulamada yaşanan değişimlerin ötesinde içsel bir değişimi ortaya koymuş, belgelerin özgünlüğü, güvenilirliği ve kanıt niteliğine yönelik yeni tartışmaların ortaya çıkmasına yol açmıştır. Ancak sağladığı hız ve etkinlik, depolama kolaylığı, kâğıt tüketimini ortadan kaldırması, kolay ve çoklu erişim vb. olanaklar, yaşanan sorunlara çözümler geliştirme sürecini hızlandırmıştır. Pek çok $A B$ ülkesinde hâlihazırda üretilen belgelerin yarısına yakını elektronik ortama taşınmıştır. Elektronik 
belgelerin güvenilirliğine dönük Elektronik İmza Kanunu pek çok ülke gibi ülkemizde de kabul edilmiştir. Yakın gelecekte ülkemizde belge işlemlerinin elektronik ortamda yürütülmesi uygulamalarının hızla yaygınlaşması beklenmektedir.

Belge yönetimi alanında asgari uyguma ölçütlerini belirlemeye dönük standartlaşma çalışmalarında 90'lı yıllarla birlikte yoğunlaşmıştır. Bu alanda iki uluslararası dernek ön plana çıkmıştır. Yeni adıyla Bilgi Yönetimi Derneği (The Association for Information Management, ARMA) ve Uluslararası Arşiv Konseyi (International Council on Archives, ICA) uluslararası kullanım değeri taşıyan pek çok düzenlemenin geliştirilmesine öncülük etmişlerdir. Örneğin ARMA/ANSI standartları ile ICA tarafından geliştirilen ISAD(G) ve ISAAR standartları alana yön çizebilmişlerdir. Öte yandan özellikle elektronik belge yönetimi alanında uygulamaların geliştirilmesine yönelik Avrupa Birliği'nce geliştirilen MoReq ile ABD/Kanada ortak çalışması sonucu ortaya çıkan DoD 5015.2 standartları önemli görülmektedir. Bu gelişmelerin uzantısı olarak ülkemizde yayımlanan Elektronik Belge Yönetimi Sistem Kriterleri Referans Modeli (EBYSKRF) uluslararası gelişmeler ve ulusal gereksinimleri örtüştüren güzel bir örnektir. Çalışma içerisinde değinilen uluslararası uygulamalarla uyumlu olarak hazırlanan Modelin, özellikle elektronik ortamda belge yönetimi çalışmalarına sağlam bir zemin oluşturacağı açıktır.

Baş döndürücü bir hızla yaşanan değişim rüzgârının hız keseceğini düşünmek mümkün görünmemektedir. Değişen koşullar belge yönetimi alanın belirli aralıklarla yeniden tanımlanmasını gerektirecek ve bu süreç süreğen olacaktır. Bu çerçevede değişime hazırlıklı olunması ve yeni koşulların yarattığı gerekliliklerinin erken kavranması önemli görülmektedir. Değişimi yakalamaktan da önemli olanın değişimin bir parçası olabilmek olduğu düşünülmektedir. Ülkemizde kamu kurumlarında belge yönetimi alanında çalışmalar genellikle "genel evrak ve arşiv müdürlüklerince" yürütülmüş, ancak belge yönetimi/arşiv ayrımı yapılmadığında meslek mensupları ile arşiv depoları özdeşleştirilmiştir.

Oysa "genel evrak" olarak adlandırılan çalışmaların bir uzmanlık alanını gerektirdiği görmezlikten gelinmiştir. Çalışma 
içerisinde değinilen ve yakın tarihlerde gerçekleştirilen düzenleme, standartlaşma ve uygulama modellerine yönelik gelişmelerin bu önyargıları kıracak nitelikte olduğu düşünülmektedir. Bu kapsamda alanda uluslararası koşullarda yaşanan gelişmelerin takip edilmesinde önemli bir aşama geçilmiş görülmektedir. Ancak değişime yön verebilmek için uluslararası alanda dernek, oluşum ve birliklerde daha fazla söz sahibi olmanın yolları aranmalıdır. Bu koşullarda belge yönetimi alanında yaşan gelişmelerin bir parçası olunması ve ulusal kimliğimizin bir ölçüde ilgili gelişmelere yansımasının yolu açılabilir.

\section{Kaynakça}

Archives and Records Assocaition of New Zelland. (2004). Selected list of national and international standards relating to records and archives. 09 Mart 2006 tarihinde http://www.aranz.org.nz/ SITE_Default/SITE_resources/standards.asp\#2 adresinden erişildi.

American National Standards Institute. (2005). ANSI/ARMA 8-2005. 18 Nisan 2006 tarihinde http://webstore.ansi.org/ansidocstore/ product.asp?sku=ANSI\%2FARMA+8\%2D2005 adresinden erişildi.

ARMA International. (2004). ANSI/ARMA 9- 2004: Requirements for electronic messages as records. 18 Nisan 2006 tarihinde http://www.arma.org/bookstore/productdetail.cfm? ProductID=1501 adresinden erişildi.

ARMA International. (2006). ARMA owerview. 11 Nisan 2006 tarihinde http://www.arma.org/ about/overview/index.cfm adresinden erişildi.

ARMA International.(2007). Standard development, process: setting standards and guidelines for profession. 1 Eylül Nisan 2007 tarihinde http://www.arma.org/standards/development/ overview.cfm adresinden erişildi.

Aytimur, S. (1997). Kalite sistem dokümantasyonu. İstanbul: Kal-Der.

Başbakanlık Teşkilatı Hakkında Kanun Hükmünde Kararnamenin Değiştirilerek Kabulü Hakkında Kanunun. (1984). Resmî Gazete, Sayı: 18550, 19 Ekim 1984. 
Benedon, W. (1999). Toward the future: the impact issues. Information Management Journal, 32(2), 5-6.

Bilgi Edinme Hakkı Kanunu. (2003). Resmî Gazete, Sayı: 25269, 24 Ekim 2003.

Bilgi Güvenliği Teşkilatı ve Görevleri Hakkındaki Kanun Tasarısı. (2007). Türkiye Bilişim Derneği. 30 Mayıs 2007 tarihinde http://www.tbd.org.tr/genel/bizden_detay.php?kod=245\&tipi= $5 \&$ sube $=$ adresinden erişildi .

Bozkurt, R. ve A. Odaman. (1999). ISO kalite güvence sistemleri: sistem kurma süreci, örnek kalite el kitabı, örnek prosedürler, talimatlar ve formlar. MPM Yay No: 549. Ankara: Milli Prodüktivite Merkezi.

Brumm, E. K. (2005). Standards: building blocks for a strong RIM program. Information Management Journal Nov/Dec, 31-39.

Cain, P. (2002). Model requirement for the management of electronic records (MoReq): A Critical Evaluation. Records Management Journal , 12(1), 14-18.

Charter of the United Nations. (1945). United Nations. 29 Mayıs 2007 tarihinde http://www.un.org/aboutun/charter/ adresinden erişildi.

Connelly, J. C. (2001). The new international records management standard: its content and how it can be used. The Information Management Journal, 35 (3), 26-36.

Çiçek, N. (2000). ISO 9000 Kalite güvence sistemi standardında evrak üretimi ve yönetimi. Arşiv Araştırmaları Dergisi, 2, 7-34.

Devlet Arşiv Hizmetleri Hakkında Yönetmelik. (1988). Resmî Gazete, Sayl: 19816, 16 Mayıs 1988.

DoD 5015.2. (2002). Design Criteria Standard for Electronic Records Management Software Application. 5 Nisan 2006 tarihinde http://www.dtic.mil/whs/directives/corres/pdf/ 50152std_061902/p50152s.pdf adresinden erişildi.

Duff, W. ve McKemmish, S. (2000). Metadata and ISO compliance. Information Management Journal, 34(1), 4:15. 
Eiring, H. L. (2002). The evolving information world. The Information Management Journal, 36(1), 20-24.

Elektronik İmza Kanunu. (2004). Resmî Gazete, Sayı: 25355, 23 Ocak 2004.

Enterprise Content Management Association. (2006). The Association for Information and Image Management. About AlIM. 11 Nisan 2006 tarihinde http://www.aiim.org/article-aiim.asp?ID=18274 adresinden erişildi.

European Committee for Standardization. (2004). Standards and Drafts. 12 Nisan 2006 tarihinde <http://www.cenorm.be/cenorm/ standards_drafts/index.asp adresinden erişildi.

Evans, D. F. (1998). Cooperation in information management. Information Management Journal, 32 (4), 32-35.

Gable, J. (2002). Everything you want to learn about DoD. Information Management Journal, November/December, 32-38.

Gringrich, L. (2006). Retention and disposition of structured data: the next frontier for records managers. The Informaton Management Journal, March-April, 31-39.

Fanning, B. (2005). Records, e-mail, security standards. Edocmagazine, Sept-Oct: 61.

Information Use Management and Policy Institute. (2006). Analysis and development of model quality guidelines for electronic records management on state and federal website: website records management in federal agencies. 7 Nisan 2006 tarihinde http://www.ii.fsu.edu/ cmcclure/nhprc\%20/nhprc_chpt_4.html adresinden erişildi.

International Council on Archives.(2006). ICA in brief. 11 Nisan 2006 tarihinde http://www.ica.org/static.php?ptextid=bref\&plangue=eng adresinden erişildi.

International Organization for Standardization (ISO). (2006). Introduction. 17 Şubat 2006 tarihinde http://www.iso.org/iso/en/aboutiso/ introduction/index.html\#thirteen adesinden erişildi.

International Records Management Trust. (2006). About us. 11 Nisan 2006 tarihinde http://www.irmt.org/about.html adresinden erişildi. 
INTERPARES.(2006). International Research on Permanent Authentic Records in Electronic Systems: INTERPARES I-II. . 7 Nisan 2006 tarihinde $\mathrm{http}: / / \mathrm{ww} w$.interpares.org/ adresinden erişildi.

ISO 15489-1. (2001). International Records Management Standard. Swistzerland: ISO/TC 46 Technical Committee:1-11. 17.02.2006 tarihinde http//www.arxiversvalecians.org/document/ISO_TR 15489- pdf. adresinden erişildi.

ISO 15489-2. (2001) Technical Report: International Records Management Standard Guidelines. Switzerland: ISO/TC 46 Technical Committee, 2001:1-24. 17 Şubat.2006 tarihinde $\mathrm{http} / / \mathrm{www}$.arxiversvalecians.org/document/ISO_TR_15489-2pdf. adresinden erişildi

Jones, V. A. (2003). Protecting records what the standards tell us. Information Management Journal, March/April 70-75.

Kaya, S. (2002). Dünya Bankası ve Türkiye. Sayıştay Dergisi, 67-68: 14029 Mayıs 2007 tarihinde http://www.sayistay.gov.tr/yayin/dergi/ icerik/der46-47m1.pdf adresinden erişildi.

Kandur, H. (2004). Bilgi Edinme Hakkı Kanunu ve kurumsal bilgi sistemleri üzerindeki etkileri. Arşiv Dünyası, 4, 5-6.

Kandur, H. (2006). Elektronik belge yönetimi sistem kriterleri referans modeli. İstanbul: Devlet Arşivleri Genel Müdürlüğü. 1 Haziran 2007 tarihinde http://www.devletarsivleri. gov.tr/EBYS_v_2_0.pdf adresinden erişildi.

Külcü, Ö. (2005). Kamu üniversitelerinde kalite yönetimi ve kalite sistem dokümantasyonu çerçevesinde belge yönetimi. Yayımlanmamış doktora tezi. Hacettepe Üniversitesi, Ankara.

Külcü, Ö. (2006). Küreselleşme sürecince Avrupa Birliği'nde belge yönetimi uygulamaları ve Türkiye. Bilgi Dünyası, 7 (2), 202-229.

McFarland, K. (2005). How to play safe on document retention. International Financial Law Review. 24(7), 69-71.

MacKenzie, G. (1999). A new world ahead: international challenges for information management. Informational Managment Journal, 33(2), 24-34. 
Milli Arşiv Kanun Tasarısı. (2007). Devlet Arşivleri Genel Müdürlüğü. 30 Mayıs 2007 tarihinde http://www.basbakanlik.gov.tr/docs/kkgm/ kanuntasarilari/milli\%20arsiv/milli\%20arsiv\%20kanunu.doc adresinden erişildi.

Mims, J. (2004). Why records cooperatives. The Information Management Journal, Nov/Dec., 47-52

Muhafazasına Lüzum Kalmayan Evrak ve Malzemenin Yok Edilmesi Hakkında Kanun. (1988). Resmî Gazete, Sayı: 19949, 04 Ekim 1988

National Archives of Australia. (2006). Archiving web sources. 5 Nisan 2006 tarihinde http://www.naa.gov.au/recordkeeping/er/ web_records/intro.html adresinden erişildi.

National Archives of United Kingdom. (2002). Functional requirements for electronic records management systems. 5 Nisan 2006 tarihinde http://www.nationalarchives.gov.uk/electronicrecords/ function.htm adresinden erişildi.

National Fire Protection Association.(2006). Overview. 17 Nisan 2006 tarihinde http://www.nfpa.org/itemDetail.asp?categorylD=495\& itemID=17991\&URL=About\%20Us/Overview adresinden erişildi.

NFPA 75. (2006).. Standards for the protection of information technology equipment. 17 Nisan 2006 tarihinde http://www.nfpa.org/ aboutthecodes/AboutTheCodes.asp? DocNum=75 adresinden erişildi.

NFPA 232. (2006). Standard for the protection of record. 17 Nisan 2006 tarihinde http://www.nfpa.org/aboutthecodes/AboutTheCodes.asp ?DocNum=232 adresinden erişildi.

NFPA 909.(2006). Code for the protection of cultural resources properties. 17 Nisan 2006 tarihinde http://www.nfpa.org/ aboutthecodes/AboutTheCodes.asp?DocNum=232 adresinden erişildi.

Organization for Economic Co-operation and Development (OECD).(2007). About OECD. 29 Mayıs 2007 tarihinde http://www.oecd.org/about/0,2337,en_2649_201185

_1_1_1_1_1,00.html adresinden erişildi. 
Özdemirci, F. (2003). İlk uluslararası belge yönetim standardı: ülkemiz açısından bir değerlendirme. Türk Kütüphaneciliği, 17(3), 225-246.

PRISM International. (2006). About PRISM International. 11 Nisan 2006 tarihinde http://www.prismintl.org/about.php adresinden erişildi.

Schlickman, J. (2003). ISO 9001:2000 Quality management system design. Boston: Artech House

Shepherth, E. and R. Pringle. (2002). Mapping descriptive standards across domains: a comparision of ISAD (G) and SPECTRUM. Journal of the Society of Archivists, 23(1), 17-34.

Shepherd, E. ve West, V. (2003). Are ISO 15489-1 2001 and ISAD(G) compatible? Part 1". Records Management Journal, 13 (1), 9-23.

Standart Dosya Planı. (2002). Başbakanlık Genelgesi, Sayı: 320-8880, 11 Haziran 2002

The Society of American Archivists. (1999). Standards for archival description: A handbook. Compiled by Victoria Irons Walch. 7 Nisan 2006 tarihinde http://www.archivists.org/catalog/stds99/ adresinden erişildi.

Spratt, R. (2004). Records management: the next ten years. RDIMS (Records, Documents and Image Management Systems). Canadian Federal Government Shared System Initiative. 17.03.2006 tarihinde http://www.rdims.com/Documents/ WhitePaper-RecordsManagement-TheNextTenYears.doc adresinden erişildi.

Sprehe, T. J. (2005). Integrating records management into information resources management in US government agencies. Government Information Quarterly, 17 (1),13-26.

Stephens, D. O. (2001). Megatrends in international records management. Information Management Journal, 35(4), 66-70.

Stephens, D. O. (2005). The why and how of international records retention. Information Management Journal, Sept-Oct, 29-35. 
T.C. Başbakanlık Dış Ticaret Müsteşarlığı(2007). Dünya Ticaret Örgütü ve Türkiye. 29 Mayıs 2007 tarihinde http://www.dtm.gov.tr/ $\mathrm{dtmweb} /$ index.cfm?action=detay\&yayinID=285\&icerikID=385\&dil $=\mathrm{TR}$ adresinden erişildi.

Türk Standartları Enstitüsü. (2007a). Bilgi ve dokümantasyon - Belge yönetimi (TSE ISO 15589-1. (2007). 1 Kasım 2007 tarihinde https://www.tse.org.tr/turkish/abone/StandardDetay.asp?STDNO= 45399\&sira $=0$ adresinden erişildi.

Türk Standartları Enstitüsü. (2007b). Bilgi ve dokümantasyon Elektronik belge yönetimi. (TSE 13298). 1 Kasım 2007 tarihinde http://www.tse.org.tr/Turkish/Abone/Standard_Ara.asp?Durum= IcsTablosu\&Sira=1\&EskiKod=01.110 adresinden erişildi

TS EN ISO 9001:2000. (2001). Kalite yönetim sistemleri: Şartları. TSE: Ankara, 1-22.

United Nations. (1996). Model law on electronic commerce. 13 Nisan 2006 tarihinde http://www.unescap.org/tid/projects/ecom04_ s4sorieul.pdf adresinden erişildi.

United Nations. (1998). E-commerce legal issues. 13 Nisan 2006 tarihinde http://www.unescap.org/tid/gateway/tisgway_ecom.pdf adresinden erişildi.

Waldron, M. (2004). Adopting electronic records management: European srategic initiatives. The Information Management Journal, July/August 2004, 31-35.

Zeaman, D. ve Healey, R. (2005). Metadata for records management in the government of Canada. Feliciter, 3, 141-143. 